\title{
Descriptions of five new species of the Neotropical cichlid genus Gymnogeophagus Miranda Ribeiro, 1918 (Teleostei: Cichliformes) from the rio Uruguay drainage
}

\author{
Luiz R. Malabarba ${ }^{1}$, Maria Claudia Malabarba ${ }^{1}$ and Roberto E. Reis ${ }^{2}$
}

Gymnogeophagus is a Neotropical cichlid genus distributed in the río Paraguay, rio Paraná and rio Uruguay drainages and also in the coastal rivers of Uruguay and southern Brazil. Its monophyly is supported by two derived features: the absence of supraneurals and the presence of a forward spine in the first dorsal-fin pterygiophore. Herein, five new species of Gymnogeophagus are described from middle to upper tributaries of the rio Uruguay drainage and from the rio Negro. All these new species belong to a clade, which includes G. gymnogenys, easily recognized by sharing two synapomorphies: the absence of an oblique bar between the dorsal border of the eye and the nape, and the possession of a black bar originating in the dorsal contour near the dorsal-fin origin and directed downward and backward on the dorsum. A key to all species of Gymnogeophagus is provided.

Gymnogeophagus é um gênero Neotropical de ciclídeos que ocorre nas drenagens dos rios Paraguay, Paraná e Uruguay e também em rios costeiros do Uruguay e do sul do Brasil. A monofilia do gênero é baseada em duas sinapomorfias: a ausência de supraneurais e a presença de um espinho dirigido para frente no primeiro pterigióforo da nadadeira dorsal. Neste trabalho são descritas cinco espécies novas de Gymnogeophagus de afluentes do médio ao alto rio Uruguai e rio Negro. Todas as espécies pertencem a um clado que inclui G. gymnogenys, facilmente reconhecido pelo compartilhamento de duas sinapomorfias: a ausência da barra cinza escura oblíqua entre a margem dorsal da órbita e a margem dorsal da cabeça, e a presença de uma barra cinza escura originando-se no dorso, anteriormente à nadadeira dorsal e direcionada para trás e para baixo na lateral do corpo. É fornecida uma chave de identificação para todas as espécies de Gymnogeophagus.

Keywords: Geophagini, Gymnogeophagus gymnogenys, Hypertrophied lips, Key of identification, Mouthbrooder cichlid.

\section{Introduction}

Cichlids are teleost fishes found chiefly in freshwaters. They constitute one of the major vertebrate families with more than 1,677 species (Eschmeyer \& Fong, 2015), of which nearly 600 inhabit the Neotropics with many species still undescribed (López-Fernández et al., 2010). Within the Cichlinae (Neotropical cichlids), the tribe Geophagini is a monophyletic clade (López-Fernández et al., 2005a, 2005b, 2010) represented in South America and southern Panama by approximately 18 genera.

The geophagin genus Gymnogeophagus was originally proposed by Miranda Ribeiro (1918) to include a single species: G. cyanopterus (= G. balzanii Perugia, 1891). Gosse (1976) included three additional species which shared the absence of supraneurals and the presence of a forward directed spine on the first dorsal-fin pterygiophore: $G$. gymnogenys (Hensel, 1870), G. rhabdotus (Hensel, 1870), and G. australis (Eigenmann, 1907). Later on, Kullander (1981) resurrected Gymnogeophagus labiatus (Hensel, 1870) from the synonymy of G. gymnogenys based on some thick-lipped specimens from Rio Grande do Sul, elevating to five the number of recognized species.

In a revisionary paper, Reis \& Malabarba (1988) described two additional species, G. lacustris Reis \& Malabarba, 1988 and G. meridionalis Reis \& Malabarba, 1988, and proposed a hypothesis of phylogenetic relationships among the seven species known at that time. In the hypothesis of Reis \& Malabarba (1988) the species of Gymnogeophagus were grouped in two clades with

\footnotetext{
${ }^{1}$ Departamento de Zoologia and Programa de Pós-Graduação em Biologia Animal, Universidade Federal do Rio Grande do Sul, Av. Bento Gonçalves, 9500, 91501-970 Porto Alegre, RS, Brazil. (LRM) malabarb@ufrgs.br (corresponding author), (MCM) maria. malabarba@ufrgs.br

${ }^{2}$ PUCRS, Laboratório Sistemática de Vertebrados, Faculdade de Biociências, Av. Ipiranga 6681, 90619-900 Porto Alegre, RS, Brazil. reis@pucrs.br
} 
distinguishing morphological and behavioral features: a short bodied, substrate brooder clade and a long bodied, mouth brooder clade, in addition to G. balzanii at the base of the tree. Ten years later, Wimberger et al. (1998) published the first molecular assessment of Gymnogeophagus relationships, including five undescribed species related to G. gymnogenys and shifting the position of $G$. balzanii to inside the mouthbrooding clade.

After the revision of Reis \& Malabarba (1988), five new species of Gymnogeophagus have been described: G. setequedas Reis, Malabarba \& Pavanelli, 1992; G. che Casciotta, Gómez \& Toresanni, 2000; G. caaguazuensis Staeck, 2006; G. tiraparae González-Bergonzoni, Loureiro \& Oviedo, 2009; and G. eocenicus Malabarba, Malabarba \& Del Papa, 2010, a fossil taxon from the Eocene Lumbrera Formation in northwestern Argentina, raising to 12 the number of described species.

In their paper, Reis \& Malabarba (1988) asserted that G. gymnogenys, as defined therein, could prove to be a group of species sharing two synapomorphies: the absence of an oblique bar between the dorsal border of the eye and the nape, and the possession of a black bar originating in the dorsal contour near the dorsal-fin origin and directed downward and backward on the dorsum. Reis \& Malabarba (1988) have tentatively included in G. gymnogenys some populations from the rio Negro, rio Santa Maria and rio Piratini, which shared these synapomorphies but presented a few differences in body shape when compared to specimens of $G$. gymnogenys from the laguna dos Patos drainage. These differences, however, showed to be overlapping when all populations were analyzed together. Thus all of them were considered to be G. gymnogenys. Pereyra \& Garcia (2008) tested the hypothesis that G. gymnogenys constitute a species complex through a Cytochrome $b(\mathrm{Cyt}$ $b$ ) analysis and found at least four lineages included in $G$. gymnogenys distributed along the lagoa Mirim, rio Negro and rio Uruguay tributaries, in Uruguay. One of these lineages corresponds to G. tiraparae recently described by González-Bergonzoni et al. (2009).

New specimens coming from Rio Grande do Sul, Brazil, and Uruguay in the last two decades, including colorful males, allowed the recognition of five new species and prompted the restriction of the distribution area of $G$. gymnogenys. Based on all this new material, we herein describe five new species distributed from the rio Quaraí, a tributary of the middle rio Uruguay, to tributaries of the upper rio Uruguay (Fig. 1), and restrict the distribution of G. gymnogenys (Fig. 2) to the laguna dos Patos and rio Tramandaí drainages in Rio Grande do Sul, Brazil and Uruguay.

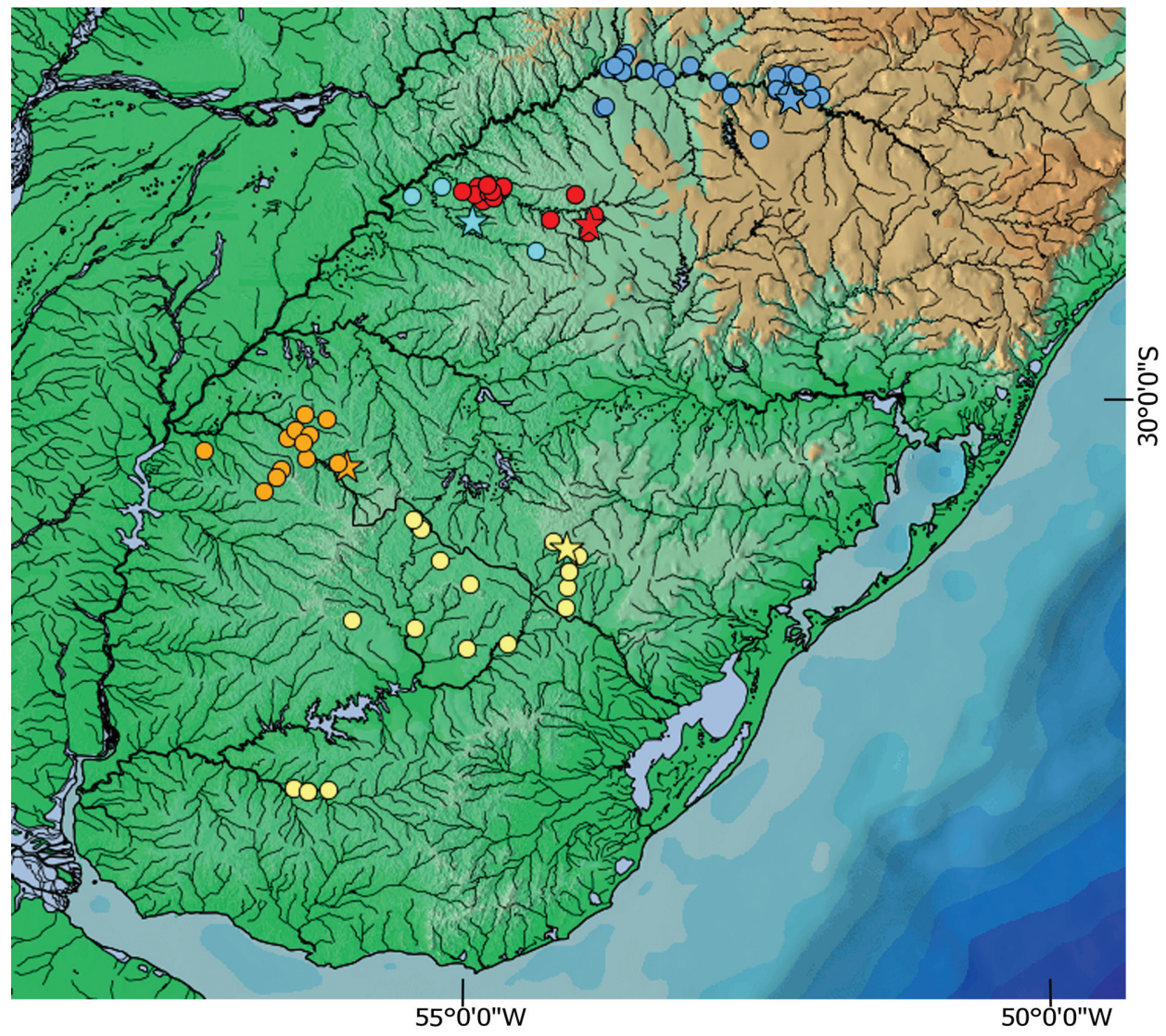

Fig. 1. Rio Uruguay and adjacent drainages showing the distribution of the examined specimens of Gymnogeophagus lipokarenos (dark blue), G. missioneiro (light blue), G. constellatus (red), G. pseudolabiatus (orange), and G. mekinos (yellow). Stars represent the type localities. 


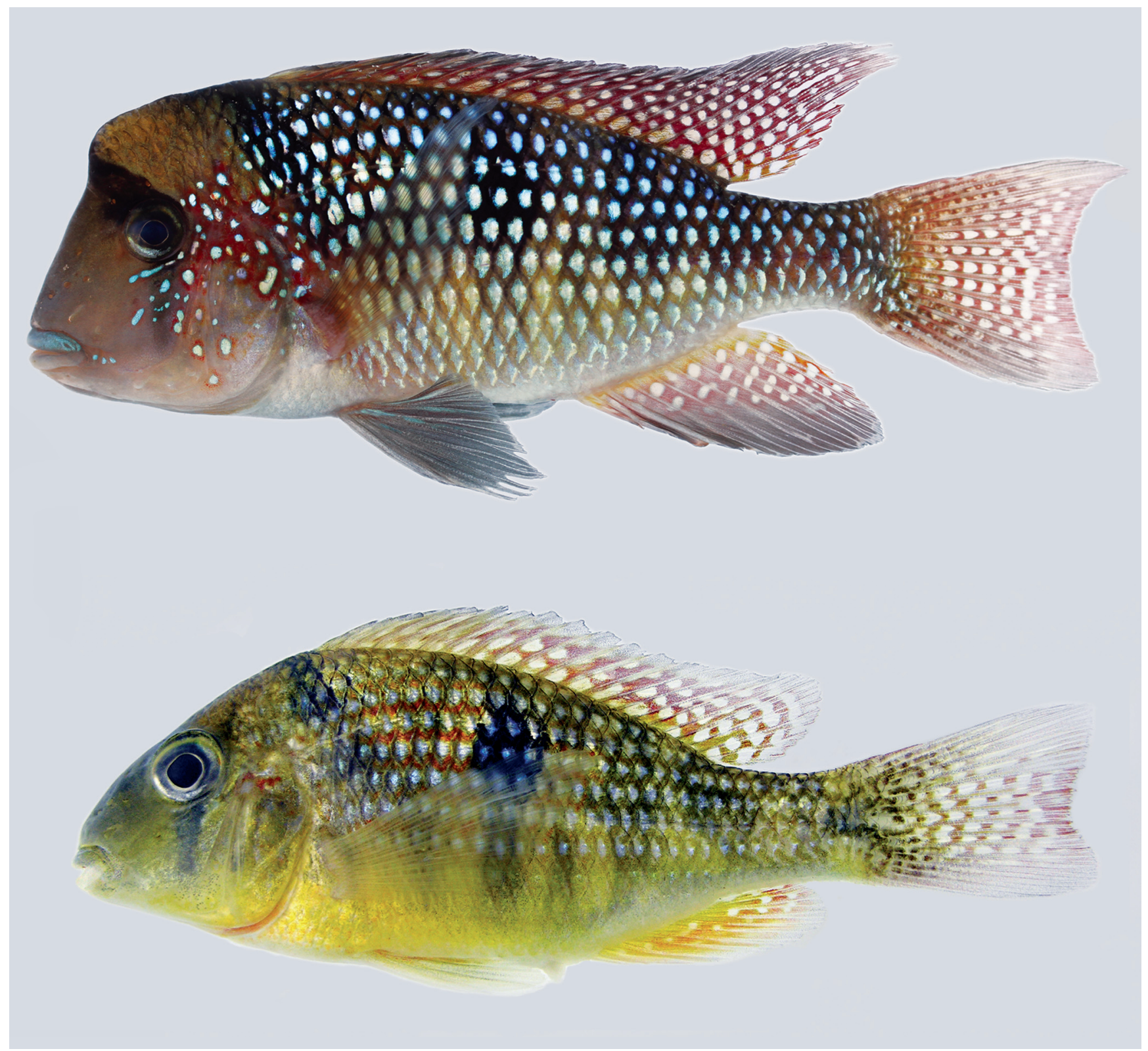

Fig. 2. Gymnogeophagus gymnogenys: top, male, UFRGS 17259, $120 \mathrm{~mm}$ SL, lagoa Corvina, Mostardas; Rio Grande do Sul, Brazil; bottom, female, uncatalogued, $84 \mathrm{~mm}$ SL, Saco da Alemoa, delta do rio Jacuí, Porto Alegre, Rio Grande do Sul, Brazil.

\section{Material and Methods}

Counts and measurements were taken according to Reis \& Malabarba (1988) and Reis et al. (1992). Meristic data are presented listing all counts followed by the number of individuals in parentheses; counts of the holotype are marked with an asterisk. Vertebral counts are presented as abdominal + caudal, including the last half centrum. Measurements were taken with a caliper on the left side of the specimens (Fig. 3). Measurements are expressed as percents of the standard length (SL) except for subunits of the head which are recorded as percents of the head length (HL). Scale row nomenclature follows
Kullander (1996). Cleared and stained specimens (C\&S) were prepared following Taylor \& Van Dyke (1985).

Institutional abbreviations are as follows: Museu Anchieta, MAPA, Porto Alegre; Museu de Ciências e Tecnologia, Pontifícia Universidade Católica do Rio Grande do Sul, MCP, Porto Alegre; Departamento de Zoologia, Universidade Federal do Rio Grande do Sul, UFRGS, Porto Alegre; University of Michigan, Museum of Zoology, UMMZ, Ann Arbor; Facultad de Ciencias de la Universidad de la Republica, ZVCP, Montevideo. Non-type specimens are listed to document distributional records and mapped in Fig. 1, but were not used in species descriptions. 


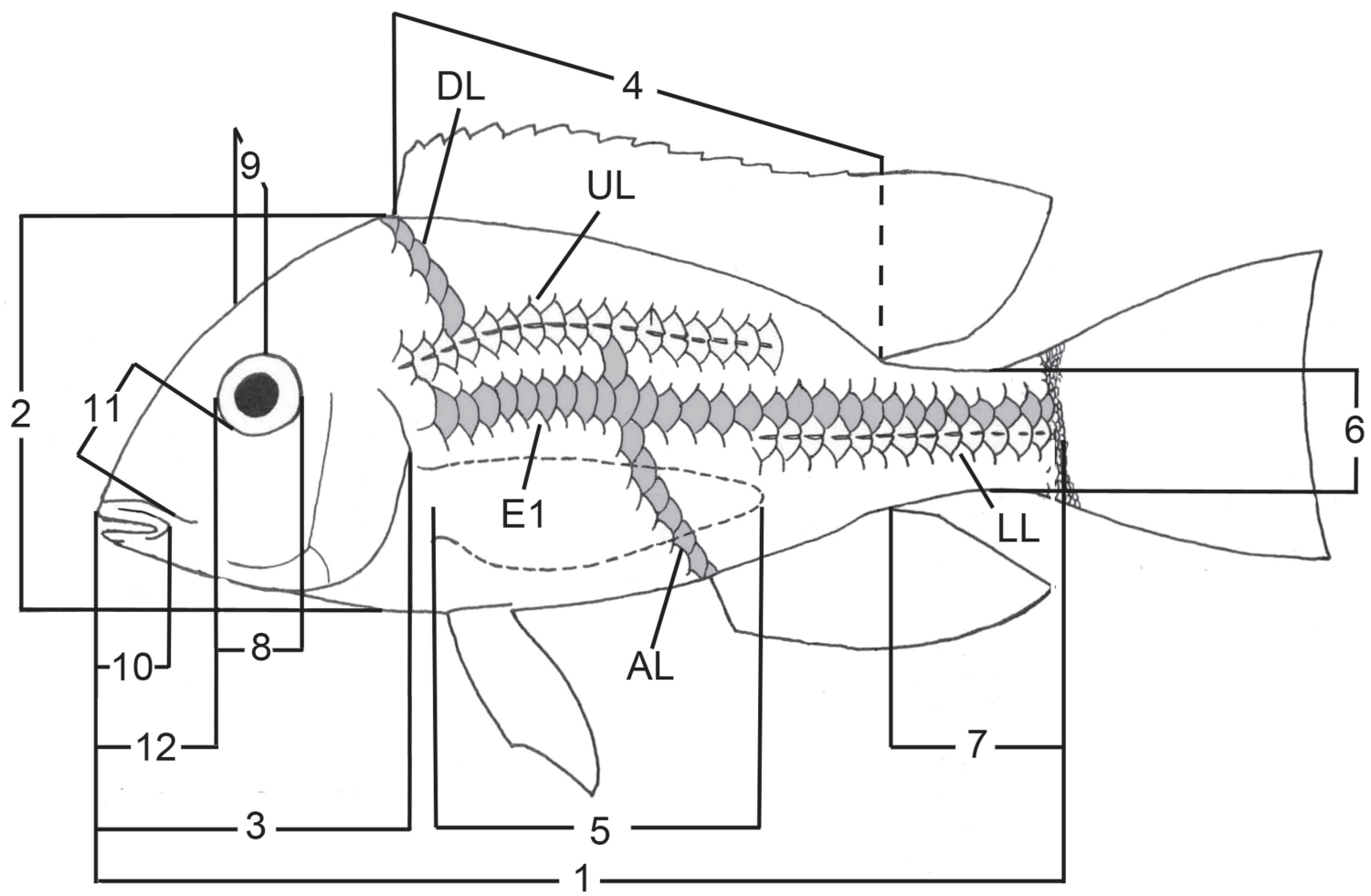

Fig. 3. Measurements and scale counts taken on examined specimens (modified from Reis \& Malabarba, 1988, and Reis et al., 1992): 1 - Standard length (SL), measured from anterior tip of upper lip to the hypural joint. 2 - Body depth, measured at the maximum depth. 3 - Head length, measured from anterior tip of upper lip to posterior bony margin of opercle. 4 - Dorsalfin base length, measured from the first spine insertion to the last soft-ray insertion. 5 - Pectoral-fin length, measured from the pectoral-fin base to the tip of the longest ray. 6 - Caudal peduncle depth, measured from the dorsal to the ventral margins of the caudal peduncle at the least depth. 7 - Caudal peduncle length, measured horizontally from the base of the last anal-fin ray to the caudal-fin base. 8 - Eye diameter, measured horizontally between orbital bony margins. 9 - Interorbital width, measured at the point of least bony width. 10 - Upper jaw length, measured from the anterior margin of the upper lip to the posterior tip of the maxilla. 11 - Pre-orbital length, measured from the lower margin of the lachrymal (just above the maxilla) to the orbital rim. 12 - Snout length, measured horizontally from the upper lip to anterior orbital rim. UL - Upper lateral line. LL- Lower lateral line. E1 - Scales in the row immediately above the row that includes the lower lateral line. DL - Scales between dorsalfin origin and upper lateral line. AL - Scales between anal-fin origin and upper lateral line.

\section{Results}

\section{Gymnogeophagus pseudolabiatus, new species}

urn:1sid:zoobank.org:act:3D1CA068-3000-4402-A45AB9DFF11B8021

Figs. 4, 5, 6a

Gymnogeophagus sp. C. -Wimberger et al., 1998 (molecular phylogeny).

Gymnogeophagus cf. gymnogenys complex - Clade 2. - Pereyra \& García, 2008 (molecular phylogeny).

Holotype. MCP 35027, male, 92.3 mm SL, Brazil, Rio Grande do Sul, Santana do Livramento, rio Sarandi III, tributary of rio Quaraí, a tributary of rio Uruguay on road from Santana do Livramento to Quaraí, 30³4'40"S 56 04'08'W, 10 Dec 1992, R. E. Reis, P. H. Wimberger \& J. F. P. Silva.
Paratypes. Brazil: Rio Grande do Sul: MCP 16123 (24, 46.9-91.1 mm SL), MCP 18294 (1, 93.9 mm SL), UMMZ $225451(10,53.1-92.6 \mathrm{~mm} \mathrm{SL})$, collected with the holotype. MCP $18371(14,44.6-69.5 \mathrm{~mm} \mathrm{SL})$, same locality as the holotype, 21 Nov 1995, J. P. Silva and others. MCP 11228 (14 alc., 3 c\&s, 42.5-87.0 mm SL), arroio Garupá, between Alegrete and Quaraí, Quaraí, approx. $30^{\circ} 04^{\prime} \mathrm{S} 56^{\circ} 14^{\prime} \mathrm{W}, 11-$ 12 Nov 1986, C. A. S. Lucena, L. A. Bergman \& P. Azevedo. MCP 11462 (1, $93.8 \mathrm{~mm} \mathrm{SL})$, tributary of rio QuaraíMirim, on road from Quaraí to Alegrete, approx. $30^{\circ} 18^{\prime} \mathrm{S}$ $56^{\circ} 23^{\prime}$ W, 12 Nov 1986, C. A. S. Lucena, L. A. Bergman \& P. Azevedo. MCP 13664 (1, $64.1 \mathrm{~mm} \mathrm{SL})$, rio Garupá, between Uruguaiana and Quaraí, 30 07'24'S 56 25'29"W, 22 Jul 1986, R. E. Reis, L. A. Bergman \& P. Azevedo. MCP 19566 (2, 31.8-27.2 mm SL), rio Quaraí-Mirim on road from Uruguaiana to Quaraí, Quaraí, 30¹5'29'S 56 30'37'W, 13 Sep 1996, W. A. Santos, J. P. Silva, V. Bertaco, E. Vidal and others. MCP 35035 (17, 67.3-39.5 mm SL) arroio Garupá tributary of rio Quaraí, on road from Quaraí to Harmonia, 
$33 \mathrm{~km}$ NE of Quaraí, Quaraí, 3009'45"S 56¹4'08”W, 25 Apr 2004, R. E. Reis, A. R. Cardoso, M. Abreu, F. Ribeiro. MCP 35036 (18, 30.1-86.5 mm SL) creek tributary of rio Quaraí, on road from Quaraí to Baltazar Brum railroad station, 30²1'52'S 56²6'23'W, 25 Apr 2004, R. E. Reis, A. R. Cardoso, M. Abreu, F. Ribeiro. MCP 35277 (10, 70.4-25.5 mm SL) arroio Mata-olho tributary of rio Quaraí, on road from Livramento to Quaraí, Quaraí, 30³2'11"S 5608'28'W, 24 Apr 2005, R. E. Reis, A. R. Cardoso, M. Abreu, F. Ribeiro. Uruguay: Artigas: MCP 17593 (12, 46.0-81.1 mm SL), arroyo Arumbeba, about $22 \mathrm{~km} \mathrm{SE} \mathrm{of}$ Artigas, 30³0'02'S 56²5'02'W, 20 Feb 1995, R. E. Reis \& C. S. Fontana. UFRGS 7754 (16, 51.6-95.9 mm SL), arroyo Cuaró Grande on Ruta 4, tributary of rio Quaraí, Artigas, 3047'03'S 5646'54”W, 8 Sep 2005, V. Bertaco, F. Cantera, J. Ferrer \& L. R. Malabarba. UFRGS 7961 (26, 90-33.9 mm SL), arroyo Yucutujá on Ruta 3, Artigas, 57 17'48'W 30²6'18'S, 9 Sep 2005. UFRGS 8001 (76,
81.5-32.1 mm SL), arroyo Tres Cruces Grandes on Ruta 4, rio Quaraí basin, Artigas, 30³5' 33's 56³7' 36”'W, 8 Sep 2005. UFRGS 8503 (56, 98.4-25.5 mm SL), arroyo Pelado on Ruta 4, rio Quaraí basin, Artigas, 30³9'33'S 5640'29”'W, 8 Sep 2005. ZVCP 10180 (10, 26.2-65.5 $\mathrm{mm}$ SL), arroyo Lemos, 30¹9'37.5”S 56³4'31.1"W, Aug 2006, M. Loureiro, Teixeira de Mello, González \& Quintans.

Diagnosis. Gymnogeophagus pseudolabiatus differs from all congeners, except G. labiatus, by the presence of thick, extremely well developed lips, with the lower lip deeply notched medially. It can be distinguished from G. labiatus by the presence of a dark band extending posteroventrally from the dorsal-fin origin (absent in G. labiatus), and by the dorsal, anal and caudal-fin color patterns, where fins are partially or completely covered with well-defined circular dots (vs. small longitudinal stripes).

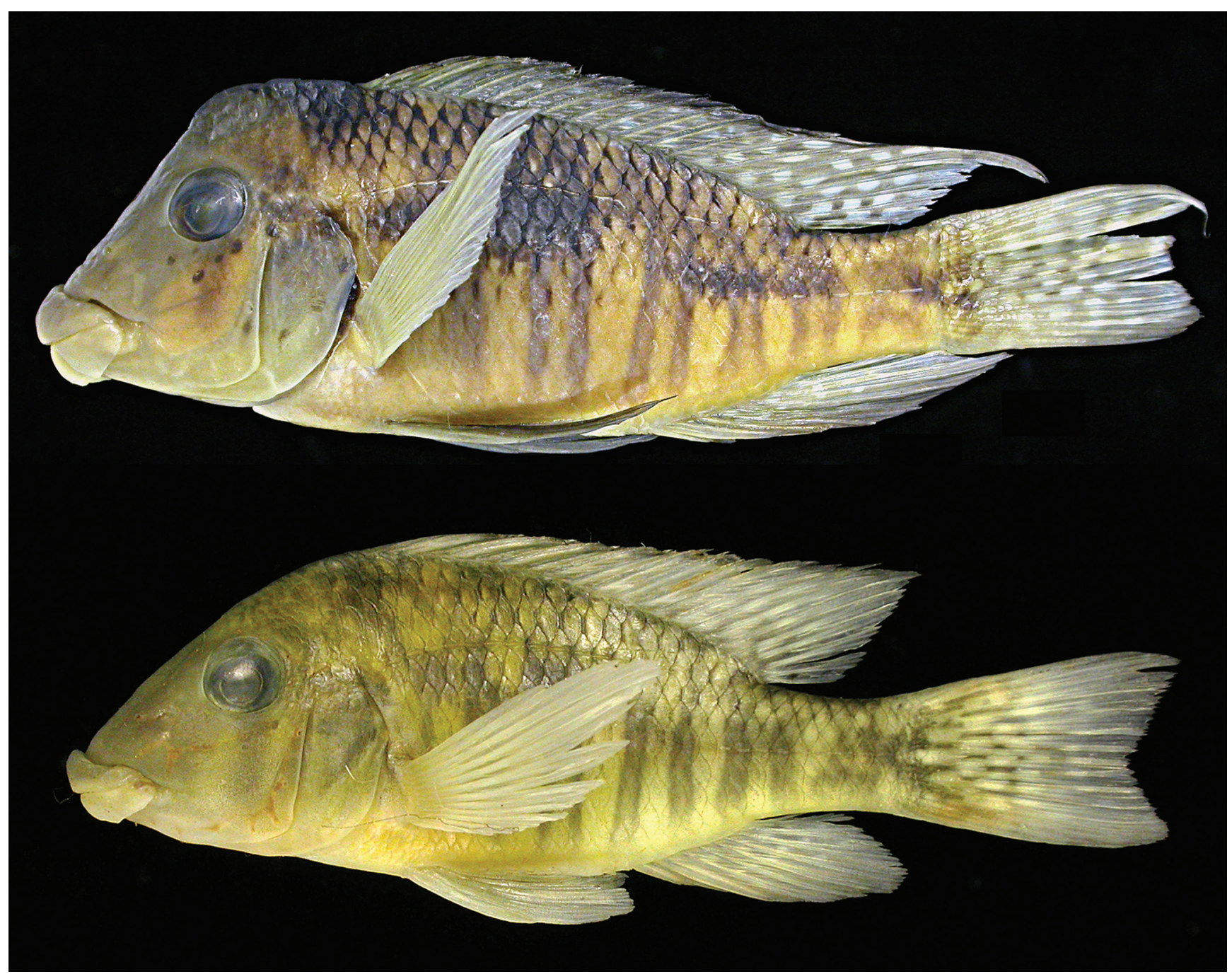

Fig. 4. Gymnogeophagus pseudolabiatus: top, holotype, male, MCP 35027, $92.3 \mathrm{~mm}$ SL, rio Sarandi III, on the road from Santana do Livramento to Quaraí, Santana do Livramento, Rio Grande do Sul, Brazil; bottom, paratype, male, MCP 35036, $81.4 \mathrm{~mm}$ SL) creek tributary of rio Quaraí, on road from Quaraí to Baltazar Brum railroad station, Rio Grande do Sul, Brazil. 

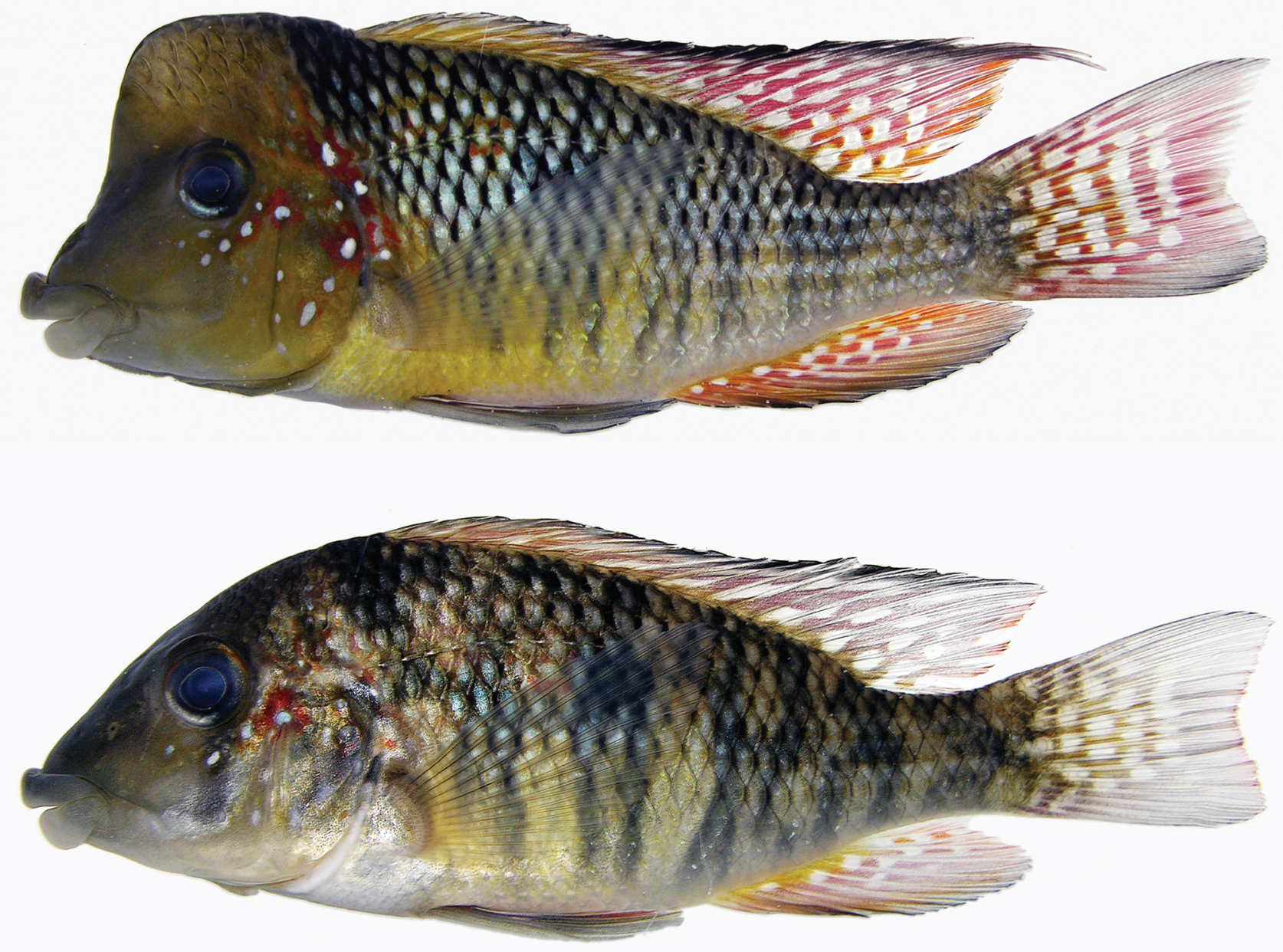

Fig. 5. Gymnogeophagus pseudolabiatus: top, paratype, male, UFRGS 7754, $102.0 \mathrm{~mm}$ SL, arroyo Cuaró Grande on Ruta 4, tributary of rio Quaraí, Artigas, Uruguay; bottom, paratype, female, UFRGS 7754, $80.5 \mathrm{~mm}$ SL, arroyo Cuaró Grande on Ruta 4, tributary of rio Quaraí, Artigas, Uruguay.

Description. Morphometric data summarized in Table 1. Body elongated, laterally compressed. Dorsal profile of head approximately straight between mouth and interorbital area and convex from interorbital region to dorsal-fin origin. Predorsal body profile modified in adult males that may show moderate adipose hump (Figs. 4a, 5a). Dorsal-fin base slightly convex. Caudal peduncle longer than deep, with dorsal and ventral profiles slightly concave.

Snout pointed, straight dorsally and ventrally in lateral aspect; narrow and anteriorly rounded in dorsal aspect. Upper and lower lips thick, large; extremely developed in adult males. Eye small, close to dorsal profile of head in juveniles and far from it at least one-half eye diameter in specimens larger than $70 \mathrm{~mm}$ SL; eye slightly posterior or near middle of head length. Interorbital area convex, more strongly in large specimens; interorbital width smaller than eye diameter in young (30-65 mm SL) and progressively larger than eye diameter in larger specimens. Posterior tip of maxilla not reaching vertical line crossing anterior margin of eye. Upper jaw longer than lower jaw.
Body scales large and ctenoid, smaller around pectoral fins; scales cycloid in preventral area. Caudal fin with single series of small ctenoid and elongated scales between contiguous rays reaching proximal third to half length of fin in both upper and lower lobes. Other unpaired fins without scales. Cheek scales cycloid in 4 to 6 rows; cheek naked anteroventrally. Upper half of opercle scaled; one vertical row of ctenoid scales in its anterior margin, not observable in all specimens. Subopercular scales ctenoid in single row. Upper lateral line $15(2), 16(1), 17 *(8)$; lower lateral line $7 *(4), 8(2)$, $9(4), 10(5), 11(2), 12(1)$, usually with 1 to 5 small perforated scales continuing onto caudal-fin base. Scales between upper lateral line and dorsal fin 4(14), $5^{*}(5)$. Scales between upper lateral line and anal fin $8^{*}(16), 9(3)$. E1 scales $25^{*}(1), 26(10)$, 27(6), 28(2).

Dorsal-fin spines 12(1), 13(8), 14*(9), 15(1); dorsal-fin soft rays $9 *(3), 10(15), 11(1)$. First dorsal-fin spine inserted at vertical line across posterior bony margin of opercle or slightly anterior to it in larger specimens. Soft dorsal fin in young and females rounded, reaching to or almost reaching caudal-fin 
base. Soft dorsal fin in mature males pointed, with 4th ray produced and reaching proximal third to almost end of caudal fin. Anal-fin with three spines and $7 *(6), 8(12), 9(1)$ soft rays. Anal-fin origin under or slightly posterior to last dorsal-fin spine; soft portion nearly rounded in young and females and clearly pointed in males. Pectoral fin pointed, more strongly in adults; 3rd and 4th rays longest, reaching vertical crossing anal-fin origin in young and females and passing that point in males. Pelvic fin pointed, more conspicuously in adult males; 2nd soft ray longest reaching region between anal opening and anal-fin origin in young and females and passing anal-fin origin in adult males. Caudal-fin posterior margin concave.

Jaw teeth small, conical, strongly recurved. Upper jaw with outer regular row of nearly 20 teeth in each premaxilla (number increasing with specimen size) and 3 or 4 indistinct irregular inner tooth bands. Lower jaw with tooth band arranged in 3-4 irregular rows; teeth larger near symphysis. Lower limb of first gill arch with 7-8 gill rakers; upper limb lobed (as in other geophagines) with 5-6 gill rakers in its margin.

Lower pharyngeal tooth plate wide; length of bone $85.7 \%$ of width; teeth covering whole occlusion surface; 21 teeth in posterior row, 17 on median row. Teeth on posterior and medial rows larger than remaining ones. Posterolateral teeth small and laterally compressed, with slightly recurved tips; posteromedial teeth much larger, cylindrical with medial, blunt cusps of molariform aspect (Fig. 6a).

Vertebrae $12+15(1), 12+17(1), 13+16(1)$ in three cleared and stained specimens.
Color in alcohol. Mature males (Fig. 4a): base color of body dark brown above longitudinal series of scales bearing lower lateral line, becoming yellowish tan below pectoral-fin insertion and in prepelvic area. Six to 9 vertical bars clearly discernible along midventral surface of body, variable in shape, distributed between pectoral-fin base and caudal peduncle. Midlateral spot not well defined, on scales 8-10 of scale row just below upper lateral line and on scales 7-9 of E1 scale row. Dark band in front of dorsal-fin origin, extending ventrally and slightly posteriorly, almost reaching first scales of upper lateral line. Head light brown, with series of conspicuous black markings surrounding eye ventrally and posteriorly, partially covering opercle. Faint vertical dark band covering cheek. Isthmus and branchiostegal membrane brownish gray. Pectoral fin hyaline. Pelvic fin dark brown. Distal border of entire dorsal fin dark brown. Spinous dorsal fin faint brown with small, narrow and inconspicuous white stripes. Soft dorsal fin faint brown covered with large number of well-defined white spots. About half distal length of anal-fin rays and spines dark brown, without additional distinct marks. Proximal half of anal-fin rays covered with small and conspicuous white dots. Caudal fin covered with white dots along almost its entire length.

Preserved coloration of females and juveniles not clearly distinct from that described for males (Fig. 4b), except for isthmus and branchiostegal membrane light yellow, instead of brown as observed in males. Presence of conspicuous vertical dark band covering cheek, below eye.
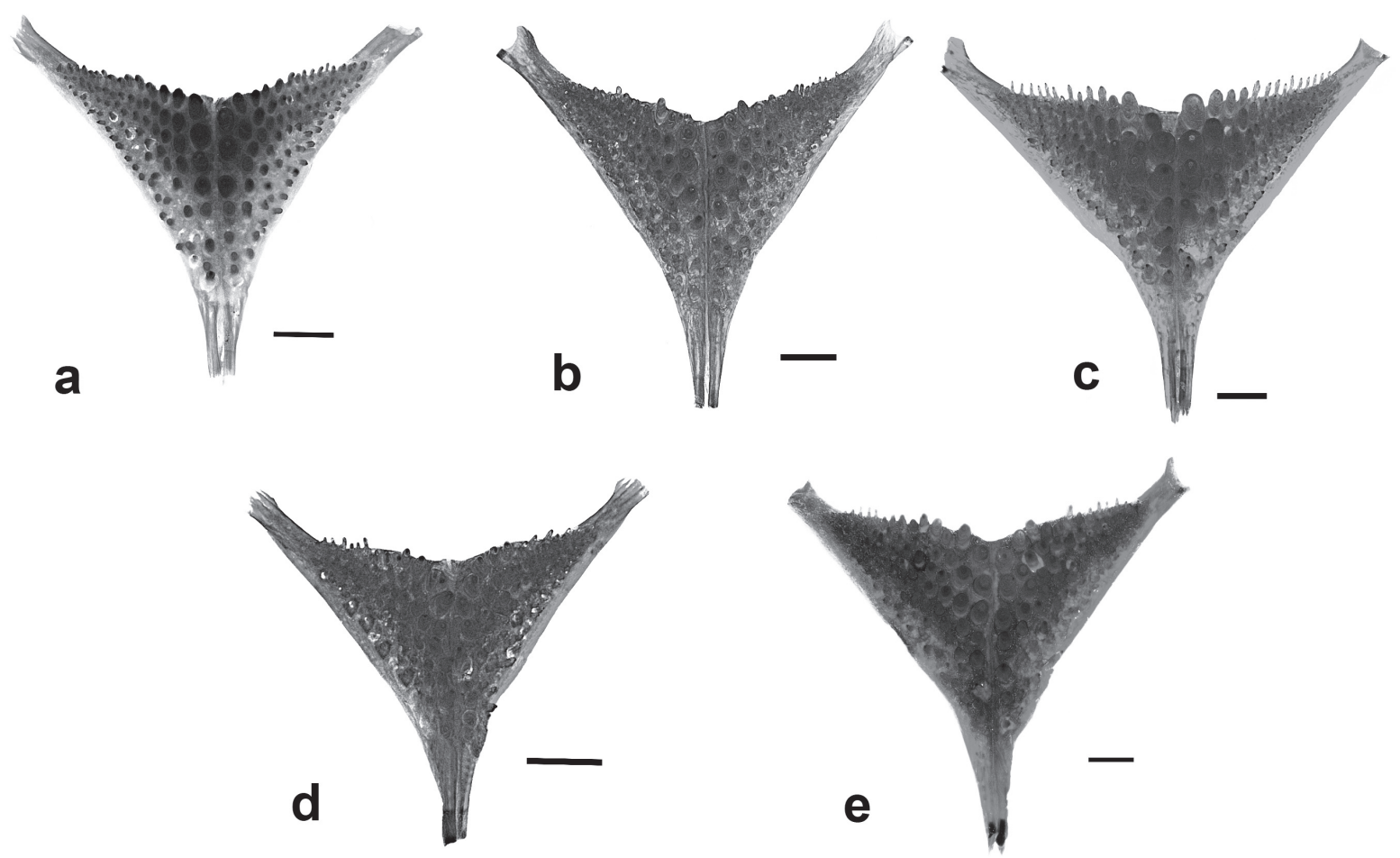

Fig. 6. Lower pharyngeal tooth plates in occlusal view: a, G. pseudolabiatus, MCP 11228, $71.6 \mathrm{~mm}$ SL; b, G. mekinos, MCP 11251, $84.2 \mathrm{~mm}$ SL; c, G. constellatus, MCP 10827, $91.4 \mathrm{~mm}$ SL; d, G. missioneiro, MCP 12725, $59.3 \mathrm{~mm}$ SL; e, G. lipokarenos, MCP 12991, $89 \mathrm{~mm}$ SL. Scale bars $=1 \mathrm{~mm}$. 
Table 1. Morphometrics for Gymnogeophagus pseudolabiatus. Specimens are from: MCP 35027 (holotype), MCP 11462, MCP 13664, MCP 11228, and MCP 18294. Ranges include holotype.

\begin{tabular}{lccccc}
\hline & Holotype & $\mathrm{n}$ & Range & Mean & SD \\
\hline Standard Length (mm) & 92.3 & 18 & $42.5-93.9$ & 70.0 & 14.3 \\
\multicolumn{5}{c}{ Percents of standard length } \\
Body depth & 37.8 & 18 & $36.5-41.9$ & 38.7 & 1.6 \\
Head length & 35.0 & 18 & $32.9-35.6$ & 34.5 & 0.7 \\
Dorsal-fin base & 50.8 & 18 & $49.5-55.8$ & 52.4 & 1.7 \\
Pectoral-fin length & 34.2 & 18 & $32.5-38.1$ & 34.8 & 1.5 \\
Caudal peduncle depth & 13.1 & 18 & $12.3-14.4$ & 13.3 & 0.5 \\
Caudal peduncle length & 17.6 & 18 & $14.3-17.6$ & 16.2 & 0.8 \\
& Percents of head length & & \\
Horizontal eye diameter & 24.5 & 18 & $24.5-30.4$ & 27.4 & 1.8 \\
Interorbital width & 25.7 & 18 & $24.0-30.5$ & 26.9 & 1.6 \\
Upper jaw length & 33.1 & 14 & $26.2-38.1$ & 30.0 & 2.9 \\
Pre-orbital width & 30.0 & 18 & $22.3-32.6$ & 28.7 & 2.9 \\
Snout length & 40.9 & 17 & $33.3-45.4$ & 41.1 & 3.2 \\
\hline
\end{tabular}

Color in life. Base color of dorsal region of body in males (Fig. 5a) olivaceous with longitudinal series of bright blue spots. Head largely yellowish green, with lips and lower jaw region pale gray. Adipose hump light brown. Red marks concentrated on opercular region and scattered over nape and anterodorsal scales. Numerous small roundish to elongate light blue spots posterior and ventral to eye and on opercle. Lateroventral portion of body yellowish brown, more intense around pectoral-fin base; yellow pale to white along isthmus and midventral regions. Anterior part of dorsal fin yellow, with hyaline thin stripes; posterior part red with numerous relatively large hyaline spots. Dorsalfin distal margin dark black dorsally and reddish orange posteriorly. Pectoral-fin hyaline and pelvic-fin dark gray. Anal fin reddish orange proximally with numerous hyaline spots, slightly smaller than those from dorsal fin. Anal fin pale red distally with dark gray distal margin. Caudal fin orange proximally and faint red distally with numerous light spots extending along its middle region. Tips of dorsal and ventral lobes dark gray.

Color in life of females (Fig. 5b) similar to that described for males, but paler. Most clear differences refer to light brown and silvery color of opercle and below pectoral fin regions, instead of yellow as observed in males. Conspicuous vertical dark band from posterior eye margin to cheek.

Distribution. Gymnogeophagus pseudolabiatus is known from the rio Quaraí and its tributaries, along the frontier of Brazil and Uruguay in the middle rio Uruguay drainage (Fig. 1).

Ecology. This species is found exclusively in stone bottom habitats covered with stones and rocks of all sizes, found along the rio Quaraí and its tributaries (Fig. 7).

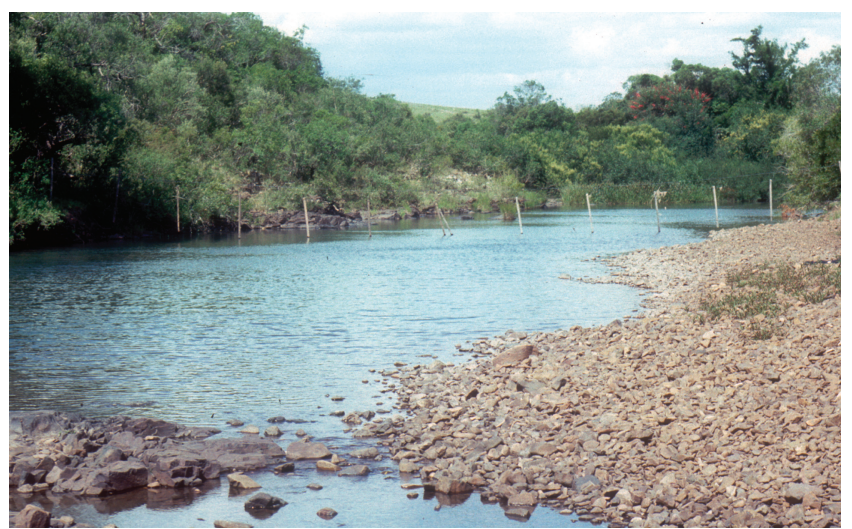

Fig. 7. Rio Sarandi III, on the road from Santana do Livramento to Quaraí, Santana do Livramento, Rio Grande do Sul, Brazil, type locality of Gymnogeophagus pseudolabiatus.

Etymology. From the Greek pseudos, meaning false, and labiatus, in reference to a congener species that also presents well developed lips. A noun in apposition.

Conservation status. Gymnogeophagus pseudolabiatus is relatively frequent and abundant in the rio Quaraí basin. Despite its Extent of Occurrence (EOO) is approximately 4,500 square kilometers, no specific threats were detected, and the species can be categorized as Least Concern (LC) according to IUCN criteria (IUCN, 2014).

\section{Gymnogeophagus mekinos, new species}

urn:1sid:zoobank.org:act:142A A25B-2A11-4770-AC4C7CDA383ED842

\section{Figs. 6b, 8}

Gymnogeophagus sp. A. - Wimberger et al., 1998 (molecular phylogeny).

Gymnogeophagus cf. gymnogenys complex - Clade 1 - Pereyra \& García, 2008 (molecular phylogeny).

Gymnogeophagus aff. gymnogenys. - Serra et al., 2014 (photo; distribution)

Holotype. MCP 19296, male, 92.4 mm SL, Brazil, Rio Grande do Sul, rio Piraizinho, on road from Bagé to Dom Pedrito, tributary of rio Negro, approximately $31^{\circ} 06^{\prime} \mathrm{S}$ 540ㄱ'W, 9 Dec 1992, J. P. Silva, R. E. Reis, P. H. Wimberger \& C. S. Fontana.

Paratypes. Brazil: Rio Grande do Sul: MCP 16119 (25, 38.3-98.8 mm SL), UMMZ 225495 (10, 49-95 mm SL), collected with the holotype. MAPA 2190 (7, 55.0-104.5 mm $\mathrm{SL}$ ), rio Negro, on road from Bagé to Dom Pedrito, approx. $31^{\circ} 08^{\prime} \mathrm{S} 54^{\circ} 22^{\prime} \mathrm{W}$. MCP 9023 (24, 46.3-79.8 mm SL), ZVCP 12958 (2, 57.7-78.9 mm SL), upper rio Negro on road from Bagé to Aceguá, Bagé, approx. $31^{\circ} 21^{\prime} \mathrm{S} 54^{\circ} 03^{\prime} \mathrm{W}, 25$ Oct 
1982, C. A. Lucena \& L. R. Malabarba. UFRGS 8396 (162, 23.0-104.1 mm SL), rio Negro on road BR-153 between

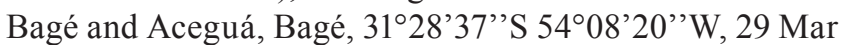
2006, L. R. Malabarba and students. Uruguay: UFRGS 7402 (26, 25.7-107.8 mm SL), arroyo Batovi on Ruta 5, $20 \mathrm{~km}$ from Tacuarembó, río Negro basin, Tacuarembó, 31 54'30"'S 56 01'14'W, 28 May 2005, L. R. Malabarba, V. A. Bertaco, P. Lehmann \& F. Cantera.

Additional non-type specimens. Brazil: Rio Grande do Sul: UFRGS 7146 (136), rio Negro, on road BR-153 between Bagé and Aceguá, Bagé, 31³6'53'S 5408'19''W, 29 Mar 2006. UFRGS 8395 (6), arroio Cinco Salsos, tributary of rio Negro, on road BR-153 between Bagé and Aceguá, Bagé, 30²8'37'’S 5408'42'W, 29 Mar 2006. UFRGS 8397 (193), arroio Piraí, tributary of rio Negro, on road BR-293 between Bagé and Dom Pedrito, Bagé, 31 ${ }^{\circ} 13^{\prime} 12^{\prime}$ 'S 5416'30'W, 30 Mar 2006. Uruguay: Rivera: UFRGS 7242 (109 alc), arroyo Corrales and lateral ponds

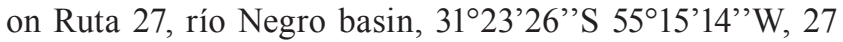
May 2005. UFRGS 7283 (3), río Negro, on Ruta 44, Paso de Mazangano, to Ruta 26, 32 $06^{\circ} 33^{\prime \prime}$ S 54 $40^{\circ} 05^{\prime \prime} \mathrm{W}, 27$ May 2005. UFRGS 7471 (79), arroyo Cuñapiru, km 12.3 of Ruta 27, río Negro basin, 3102’21'S 55²9’31’'W, 27 May 2005. UFRGS 7472 (75), arroyo Yaguari on Ruta 17, río Negro basin, 31 35'55'S 5459'19''W, 27 May 2005. Tacuarembó: UFRGS 7331 (136), río Tacuarembó on Ruta 26 in Villa

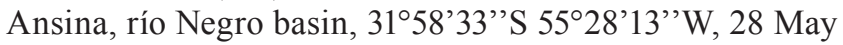
2005. UFRGS 7358 (84), río Caraguatá, tributary of río Tacuarembó on Ruta 36 in Las Toscas, río Negro basin, $32^{\circ} 09^{\prime} 29^{\prime}$ 'S 55 01 '27' W, 28 May 2005. Durazno: UFRGS 7371 (30) rio Yi on road to San Borja, río Negro basin, 33²3'49'’S 56 24'10'W, 29 May 2005. UFRGS 7394 (32) stream tributary to arroyo Maestro de Campo, on the way to Polanco de Yi, tributary of río Yi, río Negro basin, approx. $33^{\circ} 23^{\prime} \mathrm{S} 56^{\circ} 13^{\prime} 18^{\prime}$ 'W, 25 May 2005. UFRGS 7469 (9) río Yi on the city camp, río Negro basin, $33^{\circ} 21^{\prime} 45^{\prime}$ 'S $56^{\circ} 31^{\prime} 12^{\prime \prime} \mathrm{W}$, 29 May 2005. UFRGS 9434 (2) rio Yi on road to San Borja,

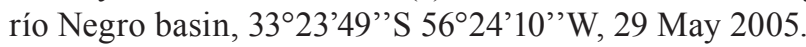

Diagnosis. Gymnogeophagus mekinos can be distinguished from all congeners, except $G$. gymnogenys, by the possession of a conspicuous and oblique dark band from the eye to the anterior border of the head in adult males (Fig. 8a). Gymnogeophagus mekinos can be distinguished from $G$. gymnogenys by the more elongate body (body depth 34.9$38.3 \% \mathrm{SL}$, mean $=36.7 \mathrm{vs} .38 .6-44.2 \% \mathrm{SL}$, mean $=40.6$ in G. gymnogenys in specimens larger than $65 \mathrm{~mm} \mathrm{SL}$ ), and by the continuous iridescent olivaceous coloration of males $v s$. the presence of clearly demarcated iridescent blue spots on the center of each scale in G. gymnogenys.

Description. Morphometric data summarized in Table 2 . Body elongated and laterally compressed. Dorsal profile of head approximately straight or slightly convex between mouth and interorbital area and convex from interorbital region to dorsal-fin origin. Predorsal body profile modified in adult males which may show small adipose hump (Fig. 8a, b). Dorsal-fin base slightly convex. Caudal peduncle longer than deep, with dorsal and ventral profile slightly concave.

Snout pointed, straight or slightly convex dorsally and ventrally in lateral aspect; narrow and anteriorly rounded in dorsal aspect. Eye small, close to dorsal profile of head in juveniles and progressively farther in larger specimens; eye slightly posterior or near middle of head length. Interorbital area convex, more strongly so in larger specimens; interorbital width smaller than eye diameter in young (up to $70 \mathrm{~mm} \mathrm{SL}$ ) and progressively larger than eye diameter in larger specimens. Posterior tip of maxilla not reaching vertical line across anterior margin of eye. Upper jaw slightly longer than lower jaw.

Body scales large and ctenoid, smaller around pectoral fins; scales ctenoid even in preventral area. Caudal fin with single series of small ctenoid and elongate scales between contiguous rays reaching about half length of fin in both upper and lower lobes. Other unpaired fins without scales. Cheek scales cycloid in 2 or 3 rows; cheek naked anteroventrally. Most of opercle scaled; one vertical row of ctenoid scales on its anterior margin. Subopercular scales ctenoid in single row. Upper lateral line 15(1), 16(5), $17 *(7), 18(5), 19(3)$; lower lateral line 7(1), 9(3), 10*(4), $11(8), 12(1), 13(4)$, usually with 1 or 2 small perforated scales continuing onto caudal-fin base. Scales between upper lateral line and dorsal fin $4 *(18)$ or $5(3)$. Scales between upper lateral line and anal fin $8^{*}(12), 9(9)$. E1 scales 26(2), 27(8), 28*(11).

Dorsal-fin spines 13(6), 14*(13), 15(2); dorsal-fin soft rays $9(2), 10 *(14), 11(5)$. First dorsal-fin spine inserted at vertical line across or slightly posterior to posterior bony margin of opercle. Soft dorsal fin in young and females rounded, reaching to or almost reaching caudal-fin base. Soft dorsal fin pointed in mature males, with 3rd and 4th or 4th and 5th ray produced and reaching proximal third to almost end of caudal fin. Anal-fin with three spines and $8(12), 9 *(5)$ or $10(1)$ soft rays. Anal-fin origin slightly posterior to last dorsal-fin spine; soft portion nearly rounded in young and females and clearly pointed in males. Pectoral fin pointed, more strongly so in adults; 3rd and 4th rays longest, passing vertical across anal-fin origin. Pelvic fin pointed, more conspicuously in adult males; 2 nd soft ray longest, reaching anal opening or region between anal opening and anal-fin origin in young and females, and passing anal-fin origin in adult males. Caudal-fin margin concave, upper lobe longest.

Jaw teeth small, conical, with slightly recurved tips. Upper jaw with outer regular row of nearly 20 teeth in each premaxilla (number increasing with specimen size) and an irregular inner tooth band of slightly smaller teeth. Lower jaw with tooth band arranged in 3-4 irregular rows. Lower limb of first gill arch with 6-7 gill rakers; upper limb lobed, with 4-5 gill rakers on its margin. 
Lower pharyngeal tooth plate slightly wider than long; length of bone $94 \%$ of width; dentigerous area covering whole occlusion surface; 21 teeth in posterior row, 17 on median row. Posterolateral teeth unicuspid, very thin with slightly recurved tips, becoming progressively smaller caudally; posteromedial teeth much larger, molariform, unicuspid, with medial cusps slightly curved anteriorly (Fig. 6b).

Vertebrae $13+15(1), 13+16(2)$ in three cleared and stained specimens.
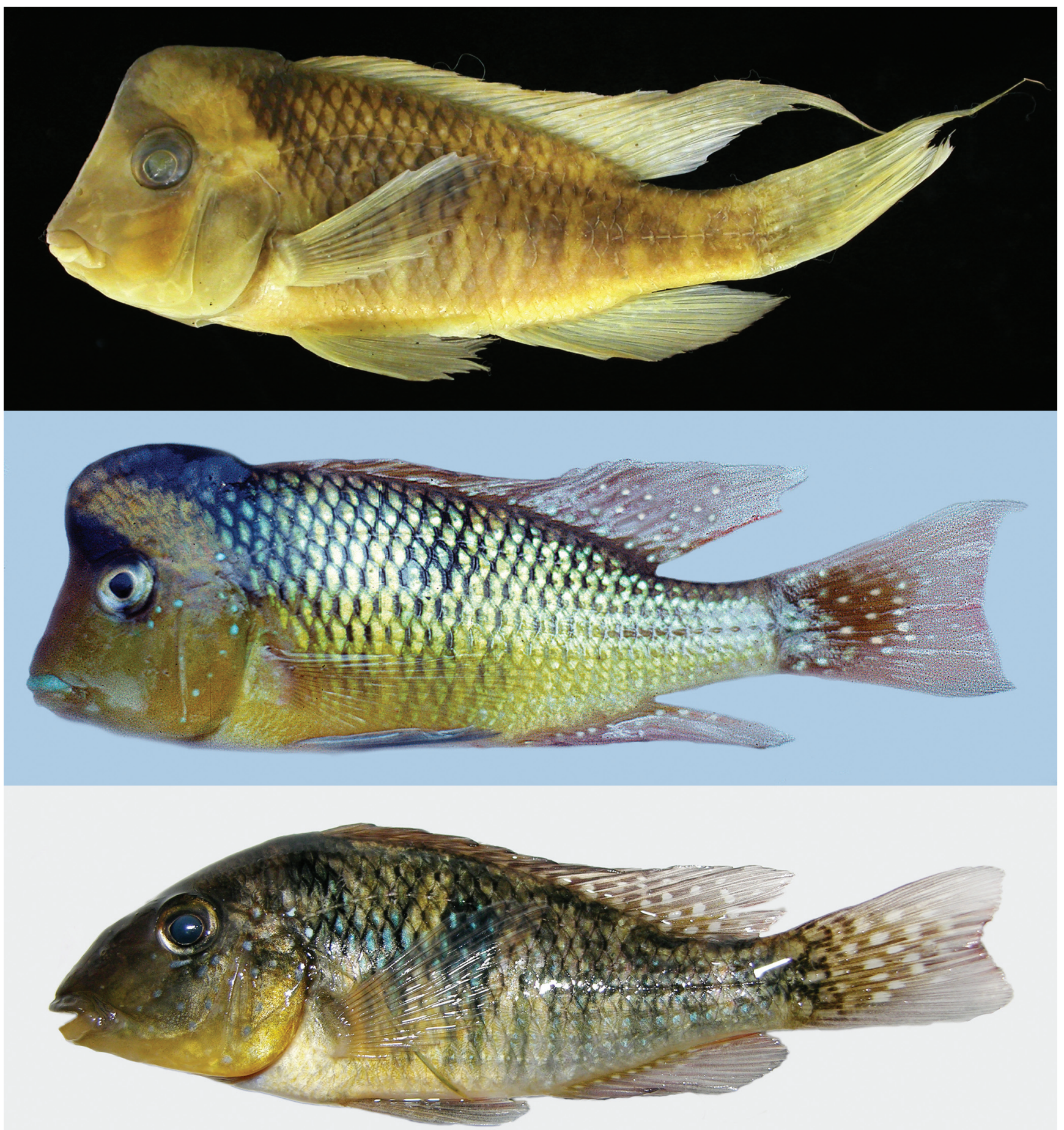

Fig. 8. Gymnogeophagus mekinos: top, holotype, male, MCP 19296, $92.4 \mathrm{~mm} \mathrm{SL}$, rio Piraizinho, on the road from Bagé to Dom Pedrito, tributary of rio Negro, Rio Grande do Sul, Brazil; middle, paratype, male, UMMZ 225495, $94.5 \mathrm{~mm}$ SL, collected with the holotype; bottom, paratype, female, UFRGS 7402, $77.5 \mathrm{~mm} \mathrm{SL}$, arroio Batovi na rota 5 à $20 \mathrm{~km}$ de Tacuarembó, no km 365,6, drenagem do rio Tacuarembó, bacia do rio Negro, Tacuarembó, Uruguay. 
Table 2. Morphometrics of Gymnogeophagus mekinos. Holotype (MCP 19296) and paratypes (MAPA 2190, MCP 9023) are from the rio Negro. Ranges include holotype.

\begin{tabular}{lccccc}
\hline Character & Holotype & $\mathrm{n}$ & Range & Mean & SD \\
\hline Standard Length (mm) & 92.4 & 21 & $51.7-104.5$ & & \\
\multicolumn{5}{c}{ Percents of standard length } \\
Body depth & 37.1 & 21 & $34.9-38.3$ & 36.8 & 1.0 \\
Head length & 35.0 & 21 & $32.9-35.6$ & 34.5 & 0.7 \\
Dorsal-fin base & 50.7 & 21 & $48.0-56.0$ & 51.4 & 2.1 \\
Pectoral-fin length & 31.4 & 21 & $31.4-36.3$ & 33.7 & 1.3 \\
Caudal peduncle depth & 13.0 & 19 & $12.5-14.0$ & 13.2 & 0.4 \\
Caudal peduncle length & 16.7 & 21 & $14.9-18.4$ & 17.1 & 0.9 \\
& Percents of head length & & \\
Horizontal eye diameter & 25.4 & 20 & $23.1-35.2$ & 30.6 & 3.0 \\
Interorbital width & 26.9 & 21 & $23.5-29.5$ & 26.5 & 1.5 \\
Upper jaw length & 31.9 & 21 & $25.9-37.3$ & 31.2 & 2.8 \\
Pre-orbital width & 30.0 & 21 & $20.8-32.3$ & 25.3 & 2.7 \\
Snout length & 38.4 & 20 & $33.8-42.7$ & 37.4 & 2.6 \\
\hline
\end{tabular}

Color in alcohol. Mature males (Fig. 8a): ground color of body light yellow, darker above longitudinal series of scales bearing lower lateral line. Vertical bars not clearly discernible. Midlateral spot not well defined, on scales 9-10 of scales row below upper lateral line and on scales 8-10 of scales row above lower lateral line. Dark band in front of dorsal-fin origin, extending ventrally and slightly posteriorly, reaching first scales of upper lateral line, and extending anteriorly through dorsal head profile. Head light brown, with black markings below eye in small males, usually not seen in larger males. Presence of conspicuous and oblique dark band from eye to anterior border of head in adult males; inconspicuous vertical dark band covering cheek, most clearly seen in small males. Isthmus and branchiostegal membrane light brown. Pectoral fin hyaline. Pelvic fin dark brown. Spinous portion of dorsal fin faint brown, usually without markings; soft portion faint brown covered with numerous small circular white spots. Distal length of anal fin spines and rays dark brown, without additional distinct marks. Proximal third of anal-fin rays covered with very small and conspicuous white dots. Caudal fin faint brown with circular white dots along its half proximal length.

Ground color in females and young light yellow. Midlateral spot as described for males. Dark band in front of dorsal-fin origin, extending ventrally and slightly posteriorly, reaching first scales of upper lateral line, but not extending anteriorly through dorsal head profile as described for males. Head yellowish brown, sometimes with black markings below eye. Conspicuous vertical dark band covering cheek. Vertical bars conspicuous in small specimens, distributed from pectoral-fin insertion to caudal peduncle. Vertical bars variable in shape. Isthmus and branchiostegal membrane light yellow.
Pectoral and pelvic fins hyaline. Dorsal fin faint brown; soft portion with small white spots. Proximal half of anal and caudal fins covered with small, circular, white spots.

Color in life. Ground color of laterodorsal region of body in males (Fig. 8b) mainly olivaceous with vertical black indistinct bars from pectoral-fin insertion to caudal fin base. Body ventrally bright yellow; pale yellow to white along prepelvic region. Head largely yellowish gray, lower lip and jaw white. Adipose hump also brown, but darker than head. Head with small light dots posteriorly to eye, and on opercle. Dark band on dorsal fin origin extending posteroventrally to upper lateral line scales. Spiny portion of dorsal fin dark yellow with short white stripes; soft portion faint red covered with light roundish spots. Caudal fin olivaceous at base and faint red at distal portion; all covered with light roundish spots. Anal fin faint red with light roundish spots on proximal third; distal portion of rays dusky. Pectoral fins hyaline, and pelvic fins darkly pigmented.

Color in life of females (Fig. 8c) similar to that described for males, but paler. Body coloration pale brown instead of olivaceous and yellow as in males. Most conspicuous difference refers to darker color of head with more numerous light dots distributed over cheek, opercle and surrounding eye. Some body scale series with bright blue spots.

Distribution. Gymnogeophagus mekinos inhabits the río Negro, connected to the lower río Uruguay (Fig. 1). Pereyra \& García (2008) have identified specimens belonging to their Clade 1 (recognized herein as $G$. mekinos) from the río Tacuarí and río Yaguarón (rio Jaguarão in Brazil) basins, both tributaries of the lagoa Mirim, laguna dos Patos drainage. The presence of freshwater fish species from the río Negro drainage in the río Tacuarí and río Yaguarón drainages has been previously reported by Loureiro et al. (2011), which also describe a characteristic elbow of capture involving the río Tacuarí and the río Negro. Although we have not examined those specimens sequenced by Pereyra \& García (2008), the presence of G. mekinos in the río Tacuarí / lagoa Mirim drainage is probable based on their DNA analysis.

Etymology. From the Greek mekinos meaning prolonged, in reference to the comparatively elongated body of this species. A noun in apposition.

Conservation status. Gymnogeophagus mekinos is relatively frequent and abundant in the rio Negro basin. The Extent of Occurrence (EOO) is approximately 23,300 square kilometers and no specific threats were detected, and the species can be categorized as Least Concern (LC) according to IUCN criteria (IUCN, 2014). 


\section{Gymnogeophagus constellatus, new species}

urn:1sid:zoobank.org:act:D4824061-DACB-49C2-9A0435DBC7E28153

Figs. 6c, 9

Holotype. MCP 10499, male, 117.3 mm SL, Brazil, Rio Grande do Sul, Ijuí, rio Conceição, 28²7’48”S 5357'17'W, 2 Dec 1985, C. Porto da Silva \& M. F. Korndorfer.

Paratypes. Brazil: Rio Grande do Sul: MCP 10478 (8, 41.0$74.0 \mathrm{~mm} \mathrm{SL}$ ), and MCP 10949 (4, 50.7-77.2 mm SL), small lagoon near rio Conceição, Ijuí, approx. 28²8'S 5358' W, 4 Dec 1985, C. Porto da Silva \& M. F. Korndorfer. MCP 10827 (16 alc., 3 c\&s, 54.0-124.5 mm SL), rio Conceição, Augusto Pestana, approx. 28³2'S 5358’W, 10 Sep 1986, C. Porto da Silva \& M. F. Korndorfer. MCP 10867 (2, 86.6-101.3 mm SL), same locality as MCP 10827, 18 Sep 1986. MCP 11863 (1, $136.8 \mathrm{~mm}$ SL), rio Potiribu, Ijuí, aprox. 28²4’S $53^{\circ} 48^{\prime}$ W, 16 Dec 1987, M. F. Korndorfer \& Winckler. MCP 34922 (3, 81.2-110.5 mm SL), arroio Pobre, tributary of rio Ijuí on road to Cerro Largo, Salvador das Missões, 2807'17'S 5450'58'W, 29 Fev 2004, A. R. Cardoso \& V. A. Bertaco. UFRGS 10420 (2, 85.74-101.2 mm SL), rio Ijuizinho, 28²5'28'S 54¹7'56”W, 11 Nov 2008, J. Ferrer \& G. Frainer. UFRGS 7094 (19, 25.9-136.1 mm SL), creek on road to Pirapó, São Nicolau, 28¹0’30"S 5504’01'W, 5 Mar 2005, M. Azevedo, J. Ferrer, L. R. Malabarba \& C. Oliveira. MCP 37021 (2, 49.9-54.6), ZVCP 12956 (2, 86.3104.6), arroio Encantado on road to BR392, tributary of rio Ijuí, Cerro Largo, 2808'32'S 5442’27’W, 31 Oct 2004, A. R. Cardoso \& V. A. Bertaco.

Additional non-type specimens. Brazil: Rio Grande do Sul: MCP 10831 (5 alc), rio Conceição, Augusto Pestanas, approx. 28³2'S 535' W, 9 Sep 1986. MCP 34866 (4 alc.), arroio Forte, tributary of rio Ijuí, Rolador, $28^{\circ} 15^{\prime} 24^{\prime \prime S}$ 5452'55'W, 01 Mar 2004. MCP 37263 (9 alc.), same locality as MCP 34866, 12 Jan 2005. MCP 34884 (3 alc.), Lageado Araçá, tributary of rio Ijuí, 16 de Novembro, 28॰12’23”S 5456'58”W, 01 Mar 2004. MCP 34915 (5 alc.), arroio Brum, tributary of rio Ijuí, Cerro Largo, $28^{\circ} 11$ '10”S 5449'36"W, 1 Mar 2004. MCP 35345 (2 alc.), same locality as MCP 24915, 12 Jun 2004. MCP 34940 (1 alc.), Lageado Cerro Azul, tributary of rio Ijuí, 28 $14^{\circ} 04^{\prime \prime S} 054^{\circ} 47^{\prime} 07^{\prime \prime} \mathrm{W}$, 01 Mar 2004. MCP 35304 (3 alc.), same locality as MCP 34940, 12 Jun 2004. MCP 37249 (7 alc.), same locality as MCP 34940, 12 Jan 2005. MCP 34951 (1 alc.), arroio Alexandrino, tributary of rio Ijuí, Salvador das Missões, 2810’25”S 5448’05'W, 29 Feb 2004. MCP 34992 (3 alc.), arroio Encantado on road to BR392, tributary of rio Ijuí, Cerro Largo, 2808'32'S 5442'27'W, 29 Feb 2004. MCP 35340 (7 alc.), arroio Albino, tributary of rio Ijuí, São Pedro do Butiá, 2808'10"S 545'28'W, 12 Jun 2004. MCP 35396 (4 alc.), arroio Pobre, tributary of rio Ijuí, Salvador das Missões, 28 ${ }^{\circ} 07^{\prime} 15^{\prime \prime S} 54^{\circ} 50^{\prime} 57^{\prime \prime} \mathrm{W}, 12$ Jun 2004. MCP 37007 (8 alc.), same locality as MCP 35396, 31 Oct 2004. MCP 37287 (10 alc.), same locality as MCP 35396, 12 Jan 2005. MCP 37006 (19 alc.), arroio Pedras, tributary of rio Ijuí, 16 de Novembro, 28 12 '07'S 05404'30"W, 30 Oct 2004. MCP 37192 (5 alc.), same locality as MCP 37006, 11 Jan 2005.

Diagnosis. Gymnogeophagus constellatus is diagnosed from other Gymnogeophagus species by the possession of a very large midlateral spot, where each scale forming the spot usually bears one large white dot (Fig. 9). In adult males, the midlateral spot almost reaches the dorsal-fin base being about 4-5 scales wide and 4 scales tall, compared with two or three scale rows distance from the dorsal fin base in other species. The midlateral spot of females and juveniles is also large, but usually not extending above the upper lateral line. Upper lateral line with 18-21 scales, usually 18-20 (vs.13-19 in all other species).

Description. Morphometric data summarized in Table 3. Body comparatively deep, laterally compressed. Dorsal profile of head convex between mouth and interorbital area in young, slightly convex or straight in adults; convex from interorbital region to dorsal-fin origin. Predorsal body profile modified in adult males that may show adipose hump (Fig. 9a, b). Dorsal-fin base slightly convex. Caudal peduncle longer than deep, with dorsal and ventral profile straight or slightly concave.

Snout pointed, somewhat blunt and rounded dorsally in young; mostly straight dorsally and ventrally in adults; narrow and anteriorly rounded in dorsal aspect. Eye small, close to dorsal profile of head in juveniles and progressively farther from it in larger specimens (at least one half eye diameter in specimens larger than $70 \mathrm{~mm}$ SL); eye slightly posterior or near middle of head length. Interorbital area convex, more strongly so in larger specimens; interorbital width smaller than eye diameter in young (up to $60 \mathrm{~mm}$ SL) and progressively larger than eye diameter in larger specimens. Posterior tip of maxilla not reaching vertical line across anterior margin of eye. Upper jaw slightly longer than lower jaw.

Body scales large and ctenoid, smaller around pectoral fins; scales ctenoid even in preventral area. Caudal fin with single series of small ctenoid and elongated scales between contiguous rays reaching proximal third to middle of fin length in both upper and lower lobes. Cheek scales cycloid in 5 or 6 rows; cheek naked anteroventrally. Opercle mostly scaled. Subopercular scales ctenoid in two irregular rows. Upper lateral line $18^{*}(12), 19(3), 20(2), 21(1)$ [18 in the holotype, but 17 th scale not perforated]. Lower lateral line $8(2), 9(1), 10(5), 11^{*}(8), 12(2)$, with none to 2 small perforated scales continuing onto caudal-fin base. Scales between upper lateral line and dorsal fin $4 *(8), 5(10)$. Scales between upper lateral line and anal fin $8 *(11), 9(9)$. E1 scales 26(3), 27*(9), 28(2), 29(1). 
Dorsal-fin spines $13^{*}(4), 14(14), 15(2)$; dorsal-fin soft rays $8(1), 9(2), 10(12), 11^{*}(5)$. First dorsal-fin spine inserted at or slightly behind vertical line across posterior bony margin of opercle. Soft dorsal fin in adult females rounded, slightly pointed in young, reaching to or almost reaching caudal-fin base. Soft dorsal fin in mature males pointed, with 4th or 5th ray longest, reaching to proximal third of caudal fin. Anal fin with three spines and $8(16)$ or $9 *(2)$ soft rays. Anal-fin origin under or slightly behind last dorsalfin spine; soft portion nearly rounded in young and females and clearly pointed in males. Pectoral fin with rounded tip in young and pointed tip in adults; 3rd and 4th rays longest, reaching vertical crossing anal-fin origin. Pelvic fin pointed, more conspicuously so in adult males; 2nd soft ray longest reaching area between anal opening and anal-fin origin in both males and females. Caudal-fin margin concave.

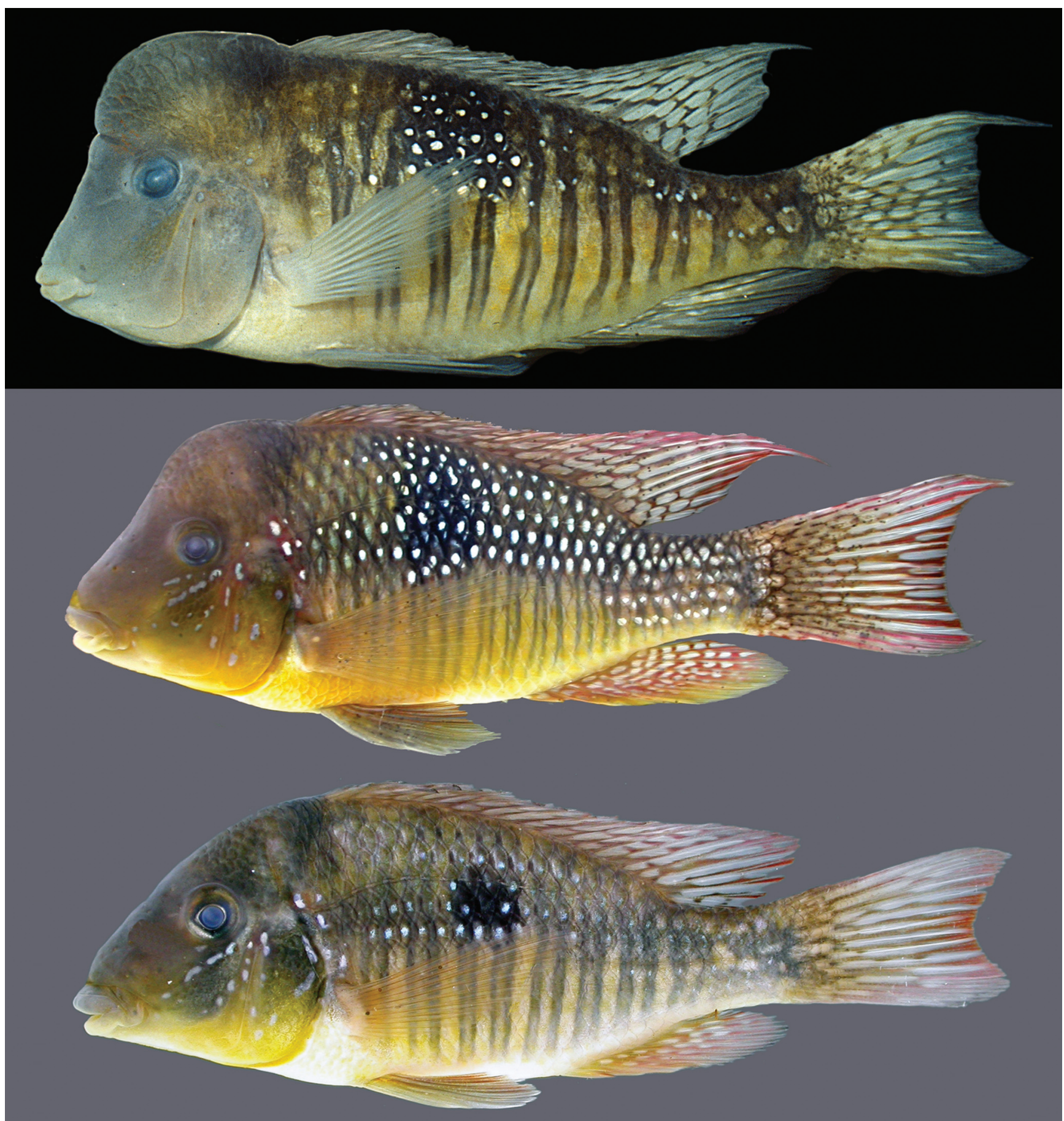

Fig. 9. Gymnogeophagus constellatus: top, holotype, male, MCP 10499, 117.3 mm SL, rio Conceição, Ijuí, Rio Grande do Sul, Brazil; middle, paratype, male, UFRGS 7094, $136.1 \mathrm{~mm}$ SL; bottom, paratype, female, UFRGS 7094, 92 mm SL, creek on the road to Pirapó, São Nicolau, Rio Grande do Sul, Brazil. 
Jaw teeth small, conical, with slightly recurved tips. Upper jaw with outer regular row of 14-25 teeth in each premaxilla (number increasing with specimen size) distinct from irregular tooth band of slightly smaller teeth. Lower jaw with narrow tooth band arranged in 3-4 irregular rows; all teeth with approximately same size. Outer hemiseries with 18-22 teeth. Lower limb of first gill arch with 7 gill rakers; upper limb lobed with 5 gill rakers on its margin.

Lower pharyngeal tooth plate wide; length of bone $78 \%$ of width; dentigerous area covering whole occlusion surface; 20-21 teeth in posterior row, 10 on median row. Anterior teeth cylindrical, erect, not recurved, unicuspid; lateral marginal teeth like anteriormost, smaller on caudal half of plate; posteromedial teeth much larger, cylindrical with medial, blunt cusps of molariform aspect (Fig. 6c).

Vertebrae $13+16$ in three cleared and stained specimens.

Table 3. Morphometrics for Gymnogeophagus constellatus. Specimens are from MCP 10499 (holotype) and MCP 10827 $(16+3 \mathrm{c} \& s)$. Ranges include holotype.

\begin{tabular}{lccccc}
\hline Character & Holotype & $\mathrm{n}$ & Range & Mean & SD \\
\hline Standard Length (mm) & 117.3 & 19 & $54.0-124.5$ & 83.0 & \\
\multicolumn{5}{c}{ Percents of standard length } \\
Body depth & 43.3 & 19 & $37.5-45.2$ & 40.3 & 2.0 \\
Head length & 33.2 & 19 & $31.2-35.1$ & 33.1 & 0.8 \\
Dorsal-fin base & 53.9 & 19 & $50.4-56.6$ & 52.8 & 1.8 \\
Pectoral-fin length & 31.2 & 19 & $29.9-35.5$ & 32.3 & 1.5 \\
Caudal peduncle depth & 13.2 & 19 & $12.3-14.6$ & 13.4 & 0.6 \\
Caudal peduncle length & 19.0 & 19 & $15.6-19.1$ & 17.4 & 0.8 \\
& Percents of head length & & \\
Horizontal eye diameter & 22.6 & 18 & $23.5-33.5$ & 27.7 & 3.1 \\
Interorbital width & 31.1 & 19 & $25.0-34.4$ & 29.6 & 2.8 \\
Upper jaw length & 30.3 & 19 & $28.4-34.2$ & 31.7 & 1.4 \\
Pre-orbital width & 40.9 & 19 & $24.4-40.9$ & 32.5 & 5.2 \\
Snout length & 48.8 & 19 & $35.0-48.8$ & 41.1 & 3.7 \\
\hline
\end{tabular}

Color in alcohol. Mature males (Fig. 9a): ground coloration light brown, darker dorsolaterally above upper lateral line, and lighter ventrally. Below pectoral-fin insertion and in preventral area whitish gray. Body covered laterally with 8 to 13 brown, double vertical bars clearly discernible along midventral lateral surface of body, distributed between pectoral-fin base and caudal peduncle; area inside double bars more pigmented than area between double bars. Number of vertical bars increases with body size among examined specimens, usually regularly arranged between pectoral and anal-fin bases and irregular in caudal peduncle. Very large midlateral spot, almost reaching dorsal-fin base on adult males; each scale in midlateral spot usually bearing one large white dot. Midlateral spot of mature males covering scales 8-9 to 11-12 of scale row just above upper lateral line, scales 8-12 of upper lateral line, scales 8-12 of scale row just below upper lateral line and scales 8-11 of E1 scale row. Dark band in front of dorsal-fin origin small, not extending ventrally and posteriorly. Head dark brown, with small series of black markings ventral to eye and very few black spots along opercle and preopercle borders. Distinct dark band covering cheek absent. Isthmus and branchiostegal membrane ligth brown. Pectoral fin hyaline. Pelvic fin somewhat dusky. Spinous dorsal fin with white stripes, and soft dorsal fin covered with very large white dots, sometimes elongated at distal tip and forming large white areas. Proximal half-length of anal-fin rays covered with conspicuous white spots; anal-fin distal border whitish gray. Caudal-fin base covered with large white dots, large and elongated on distal portion of fin.

Color in alcohol of preserved females and juveniles similar to general pattern described for males. Midlateral spot in females smaller than in males, usually not extending above upper lateral line as described for males. Midlateral spot of females and juveniles with fewer white dots centered and not on each scale as described for males. Dark band in front of dorsal-fin origin clearly extending ventrally and posteriorly.

Color in life. Ground coloration of males (Fig. 9b) olivaceous dorsolaterally with longitudinal series of bright spots. Head largely yellowish green, with adipose hump and snout light brown. A few red marks on opercle, preopercle and cleithrum. Numerous small roundish to elongate light blue spots ventral to eye and on opercle. Lateroventral portion of body yellow, becoming pale yellow near to anal-fin base and caudal peduncle. Ground color of dorsal fin red, covered with conspicuous light spots which increase distally until forming large white stripes. Pectoral-fin hyaline and pelvicfin yellowish gray. Anal fin red proximally with numerous white spots; pale yellow with no spots distally. Caudal fin brown on proximal third and pale red distally; numerous white spots covering its base, which become stripes toward caudal margin.

Color in life of females (Fig. 9c) similar to that described for males, but much paler. Longitudinal series of bright spots less evident. Most clear differences refer to light brown coloration lateroventrally instead of yellow as in males. Dark band from dorsal-fin origin extending ventrally to scales below upper lateral line. Midlateral spot smaller than in males.

Distribution. Gymnogeophagus constellatus is known from the rio Ijuí and its tributaries in the middle rio Uruguay basin, in the eastern portion of Rio Grande do Sul, Brazil (Fig. 1).

Etymology. From the Latin constellatus meaning studded with stars, in reference to arrangement of white bright spots in the dorsolateral region of the body. An adjective in masculine form.

Conservation status. Gymnogeophagus constellatus is relatively frequent and abundant in the rio Ijuí basin. 
Despite the Extent of Occurrence (EOO) is approximately 2,300 square kilometers and hydroelectric dams exist in that basin, no specific threats were detected, and the species can be categorized as Least Concern (LC) according to IUCN criteria (IUCN, 2014).

\section{Gymnogeophagus missioneiro, new species}

urn:1sid:zoobank.org:act:5CF 8798C-A9C1-4492-9E0842A12A8D7BDF

\section{Figs. 6d, 10}

Gymnogeophagus sp. D. - Wimberger et al., 1998 (molecular phylogeny).

Holotype. MCP 23495, male, 109.3 mm SL, Brazil, Rio Grande do Sul, $4 \mathrm{~km}$ from São Luiz Gonzaga, arroio Ximbocuzinho, on road from São Luiz Gonzaga to

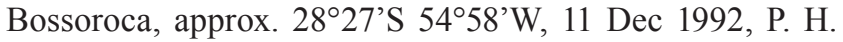
Wimberger, R. E. Reis, J. F. P. Silva \& C. S. Fontana.

Paratypes. Brazil: Rio Grande do Sul: MCP 16125 (17, 16.6$75.8 \mathrm{~mm} \mathrm{SL})$, UMMZ 225488 (7, 52-77 mm SL), collected with the holotype. MCP 10881 (2, 65.5-125.3 mm SL), rio Piratini at Coimbra district, Santo Ângelo, approx. $28^{\circ} 42^{\prime} \mathrm{S}$ 542ㄱ'W,19 Dec 1985, L. R. Malabarba, R. E. Reis \& S. B. Mallmann. MCP 12618 (12, 36.6-108.3 mm SL), arroio Canoin, on road from Pirapó to São Nicolau, approx. $28^{\circ} 08^{\prime} \mathrm{S}$ 55¹4’W, 2 Nov 1988, C. A. Lucena, L. A. Bergmann, E. H. Pereira and others. MCP 12725 (10 alc., 2 c\&s, 46.7-109.1 mm SL), arroio Passo do Rosário or Passo da Cancela, on road from São Nicolau to Garruchos, Santo Antônio das Missões, approx. $28^{\circ} 13^{\prime} \mathrm{S} 55^{\circ} 30^{\prime} \mathrm{W}, 3$ Nov 1988, C. A. Lucena, P. Azevedo, L. A. Bergmann \& E. H. Pereira.

Diagnosis. Gymnogeophagus missioneiro differs from congeners, G. balzanii, G. meridionalis, G. rhabdotus, G. setequedas, G. labiatus and G. lacustris by the absence of an oblique dark band from the eye to the origin of the dorsal fin. Gymnogeophagus missioneiro differs from the remaining species by the absence of an oblique dark band from the eye to the anterior border of the head in mature males (vs. present in G. gymnogenys and G. mekinos); the unpaired fins colored red (vs. yellow in G. lipokarenos); soft dorsal fin rarely scaled (vs. soft dorsal fin scaled in G. australis); the presence of large white dots sometimes forming stripes distally in the soft dorsal fin (vs. dorsal fin of males with spaced small silvery to bright blue dots in G. caaguazuensis, and dorsal fin of males with three longitudinal bands colored of yellow proximally, white/red at middle length of dorsal fin spines and rays and dark gray distally in G. tiraparae); the caudal fin covered with white dots ( $v s$. caudal fin covered with dots proximally and stripes distally in G. constellatus); and the lips not developed (vs. lips developed in G. pseudolabiatus).
Description. Morphometric data summarized in Table 4. Body elongate, laterally compressed. Dorsal profile of head convex between mouth and interorbital area in young, slightly convex or straight in adults; convex from interorbital region to dorsal-fin origin. Predorsal body profile modified in adult males by small adipose hump (Fig. 10a, b). Dorsalfin base slightly convex. Caudal peduncle longer than deep, with dorsal and ventral profile slightly concave.

Snout pointed, slightly blunt and rounded dorsally in young; mostly straight dorsally and ventrally in adults; narrow and anteriorly rounded in dorsal aspect. Eye small, close to dorsal profile of head in juveniles and progressively farther in larger specimens (about one half eye diameter in specimens larger than $70 \mathrm{~mm} \mathrm{SL}$ ); eye slightly posterior or near middle of head length. Interorbital area convex, more strongly so in larger specimens; interorbital width smaller than eye diameter in young (up to $50 \mathrm{~mm} \mathrm{SL}$ ) and progressively larger than eye diameter in larger specimens. Posterior tip of maxilla not reaching to vertical line across anterior margin of eye. Upper jaw slightly longer than lower jaw.

Body scales large and ctenoid, smaller around pectoral fins; scales cycloid in preventral area. Caudal fin with single series of small ctenoid and elongated scales between contiguous rays reaching one half length of fin in both upper and lower lobes. Soft portion of dorsal fin of males without scales between contiguous rays. Cheek scales cycloid in 5 or 6 rows; cheek naked anteroventrally. Opercle mostly scaled, especially dorsally. Subopercular scales ctenoid in one or two irregular rows. Upper lateral line 13(1), 15(1), 16(1), 17(3), 18*(2), 19(1). Lower lateral line 5(1), 8(4), 9(2), $11 *(1), 12(1)$, with 1 to 3 small perforated scales continuing onto caudal-fin base. Scales between upper lateral line and dorsal fin $4^{*}(4), 5(5)$. Scales between upper lateral line and anal fin $8^{*}(3), 9(6)$. E1 scales 26(3), 27*(5), 28(1).

Dorsal-fin spines 13(3), 14*(4), 15(2); dorsal-fin soft rays $10 *(7), 11(2)$. First dorsal-fin spine inserted at or slightly anterior to vertical line across posterior bony margin of opercle. Soft dorsal fin in young rounded, slightly pointed in adult females, reaching or almost reaching caudal-fin base. Soft dorsal fin in mature males pointed, with 3rd or 4th ray longest, reaching proximal third to one half length of caudal fin. Anal-fin with three spines and 8(8) or $9^{*}(1)$ soft rays. Anal-fin origin under last dorsal-fin spine; soft portion nearly rounded in young and females and clearly pointed in males. Pectoral fin with rounded tip in young and slightly pointed in adults; 3 rd and 4th rays longest, reaching to or slightly passing vertical crossing anal-fin origin. Pelvic fin pointed, more conspicuously so in adult males; 2nd soft ray longest reaching area between anal opening and anal-fin origin in both males and females, sometimes passing analfin origin in mature males. Caudal-fin margin truncated or slightly concave.

Jaw teeth small, conical, recurved. Upper jaw with irregular outer row of 18-24 teeth in each premaxilla (number increasing with specimen size). Anterior tip of lower jaw wide, tooth band arranged in 5 or 6 irregular 
rows; middle and posterior tooth band slender, arranged in 3 or 4 irregular rows. Teeth at anterior tip of dentary thicker than other dentary and premaxillary teeth. Nearly
18 teeth in outer hemiseries. Lower limb of first gill arch with 7-8 gill rakers; upper limb lobed with 4-7 gill rakers on its margin.
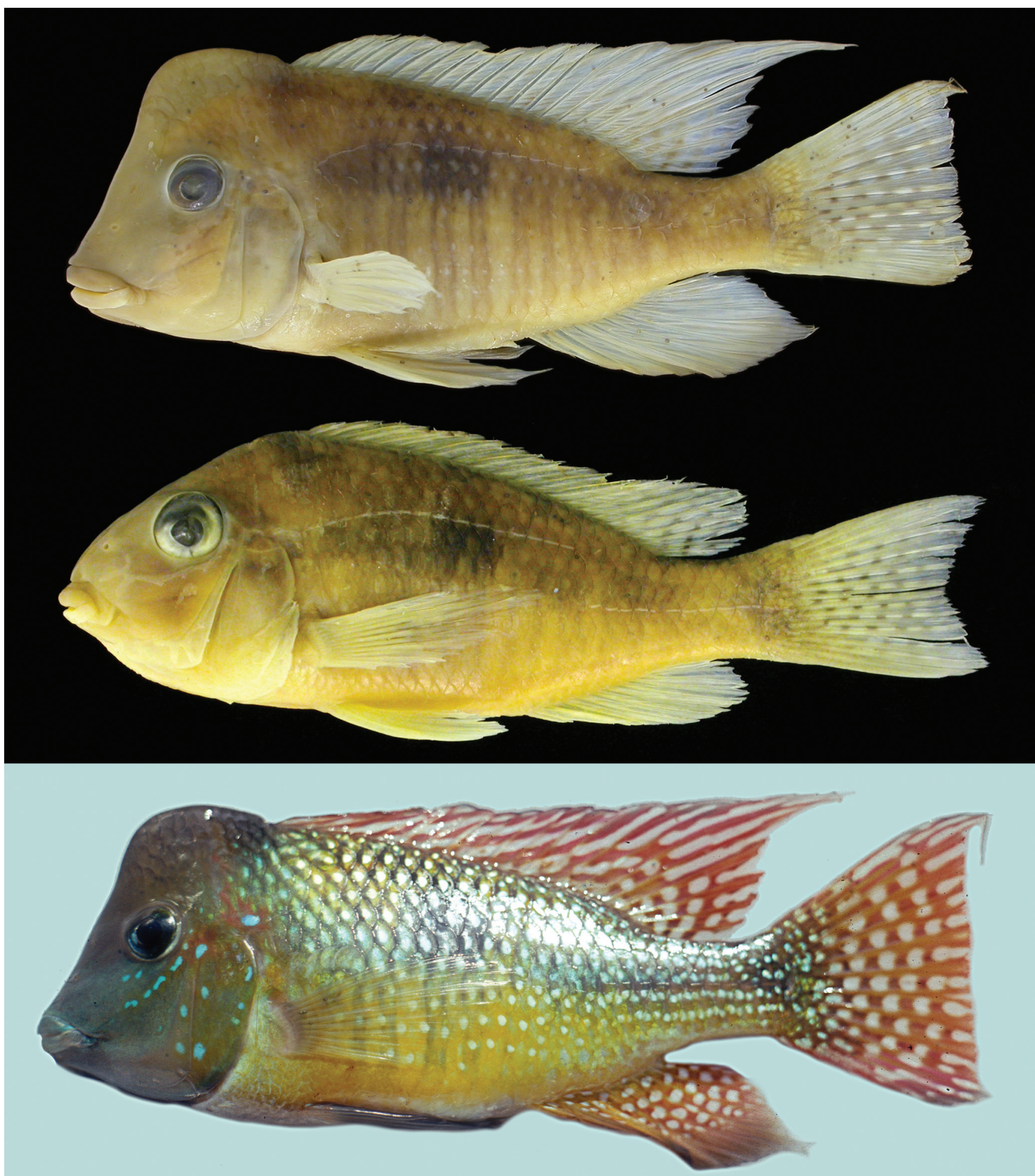

Fig. 10. Gymnogeophagus missioneiro: top, holotype, male, MCP 23495, $109.3 \mathrm{~mm}$ SL, arroio Ximbocuzinho, on the road from São Luiz Gonzaga to Bossoroca, 4 km from São Luiz Gonzaga, Rio Grande do Sul, Brazil; middle, paratype, female, MCP 12725, $72.8 \mathrm{~mm}$ SL, arroio Passo do Rosário or Passo da Cancela, on the road from São Nicolau to Garruchos, Santo Antônio das Missões, Rio Grande do Sul, Brazil; bottom, holotype, photo taken just after capture. 
Lower pharyngeal tooth plate slightly wider than long; length of bone $96 \%$ of width; dentigerous area covering whole occlusion surface; 19 teeth in posterior row, 17 on median row. Lateral marginal teeth smaller on caudal half of plate; posteromedial teeth much larger, cylindrical with medial, blunt cusps of molariform aspect (Fig. 6d).

Vertebrae $13+16$ in two cleared and stained specimens.

Table 4. Morphometrics for Gymnogeophagus missioneiro. Specimens are from MCP 23495 (holotype) and MCP 12725. Ranges include holotype.

\begin{tabular}{lccccc}
\hline Character & Holotype & $\mathrm{N}$ & Range & Mean & SD \\
\hline Standard Length (mm) & 109.3 & 8 & $58.2-109.3$ & 77.3 & \\
\multicolumn{5}{c}{ Percents of standard length } \\
Body depth & 40.5 & 8 & $37.8-43.5$ & 41.1 & 1.9 \\
Head length & 33.5 & 8 & $32.3-36.3$ & 34.7 & 1.5 \\
Dorsal-fin base & 52.2 & 8 & $51.4-55.2$ & 53.4 & 1.3 \\
Pectoral-fin length & 32.5 & 8 & $30.4-34.4$ & 32.3 & 1.3 \\
Caudal peduncle depth & 13.0 & 8 & $12.7-14.2$ & 13.4 & 0.6 \\
Caudal peduncle length & 18.6 & 7 & $15.3-18.6$ & 16.2 & 0.6 \\
& Percents of head length & & \\
Horizontal eye diameter & 25.1 & 7 & $23.1-30.6$ & 27.7 & 2.5 \\
Interorbital width & 30.9 & 8 & $25.0-34.9$ & 29.5 & 2.8 \\
Upper jaw length & 35.2 & 8 & $29.8-36.9$ & 32.7 & 2.2 \\
Pre-orbital width & 34.4 & 8 & $29.8-41.1$ & 32.8 & 4.2 \\
Snout length & 43.7 & 8 & $35.3-48.8$ & 42.1 & 5.2 \\
\hline
\end{tabular}

Color in alcohol. Mature males (Fig. 10a): ground color of body pale brown above longitudinal series of scales bearing lower lateral line, becoming yellowish below pectoralfin insertion and in preventral area. Vertical bars clearly discernible along midventral surface of body, between pectoral-fin base and caudal peduncle, not discernible in caudal peduncle. Midlateral spot on scales 8-11 of upper lateral line and on two scale rows below upper lateral line. Dark band in front of dorsal-fin origin small, extending ventrally and slightly posteriorly. Head light brown, with series of dark gray markings ventral and posterior to eye and on opercle; dusky on snout and hump. Dark band covering cheek absent. Isthmus and branchiostegal membrane pale brown. Pectoral fin hyaline; pelvic fin light brown. Spinous dorsal fin and anterior portion of soft dorsal fin faint brown with narrow white stripes. Posterior portion of soft dorsal fin faint brown covered with relatively large circular white spots. Proximal two thirds of anal-fin rays with white dots. Distal third of anal fin rays and spines dark brown, without additional distinct marks. Caudal fin faint brown with circular white dots along its entire length. Color in alcohol of preserved females (Fig. 10b) and juveniles similar to that of males, but vertical bars hardly discernible. Isthmus and branchiostegal membrane light yellow, and pelvic fins hyaline.

Color in life. Ground color of dorsal region of body in males (Fig. 10c) olivaceous with longitudinal series of bright spots. Head largely brownish green with irregular red markings on opercle and immediate posterior area. Adipose hump brown, but darker than head. Vertical bars hardly discernible. Head with series of light blue dots under and posteriorly to eye, on opercle and preopercle. Lateroventral portion of body dark yellow, more intense around pectoral-fin base; yellow pale to gray along isthmus and prepelvic region. Dorsal fin red covered with light roundish spots proximally and light stripes distally. Caudal fin red entirely covered with light roundish spots aligned between rays. Anal fin orange on base, red in middle and dusky in distal portion. Pectoral fins hyaline; pelvic fins darkly pigmented.

Distribution. Gymnogeophagus missioneiro is known from the rio Piratini and its tributaries, middle rio Uruguay basin, in the western portion of Rio Grande do Sul, Brazil (Fig. 1).

Etymology. Missioneiro, a Portuguese noun meaning from the Missões region, the Jesuitic Missions of the Eighteenth century in southern Brazil and Argentina, in allusion to the distribution of this species. A noun in apposition.

Conservation status. Gymnogeophagus missioneiro used to be relatively abundant but not very frequent in the rio Piratini basin until about 20 years ago. Recent collecting efforts in the area, including the type and paratype localities, failed to catch additional specimens. Its Extent of Occurrence (EOO) is approximately 1,200 square kilometers, and there is a significant continued decline in habitat quality by the extensive agriculture in the rio Piratini basin, both by pesticide runoff and siltation. On the other hand, the population is neither severely fragmented nor presenting extreme fluctuations, and the species is thus categorized as Near Threatened (NT) according to IUCN criteria (IUCN, 2014).

\section{Gymnogeophagus lipokarenos, new species}

urn:1sid:zoobank.org:act:205B6DAA-6A95-4D7D-A29AA064512F110E

Figs. 6e, 11, 12

Gymnogeophagus sp. E. - Wimberger et al., 1998 (molecular phylogeny).

Holotype. MCP 23522, male, $108.5 \mathrm{~mm}$ SL, rio Dourados at Linha Várzea, on road from Severiano de Almeida to Aratiba, Rio Grande do Sul, Brazil, approx. 27²3'S 52 ${ }^{\circ} 13^{\prime} W, 12$ Dec 1992, P. H. Wimberger, R. E. Reis \& C. S. Fontana.

Paratypes. Brazil: Rio Grande do Sul: MCP 16127 (8, 68.2$119.8 \mathrm{~mm} \mathrm{SL})$, UMMZ 225381 (8, 71-85 mm SL), collected with the holotype. MCP 12958 (34 alc, 3 c\&s, 48.7-124.4 mm SL), ZVCP 12957 (2, 88.9-99.8 mm SL), rio Dourados 
between Três Barras and Mariano Moro, Mariano Moro,

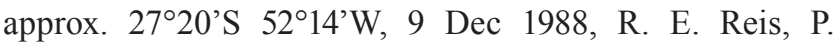
Azevedo, A. C. Bergmann, E. H. Pereira \& A. Ramires. Santa Catarina: MCP 12996 (14, 55.3-104.1 mm SL), rio Jacutinga on road BR-283 from Seara to Concórdia, Concórdia, 2711'15”'S 52॰10’03”W, 8-10 Dec 1988, R. E. Reis, A. C. Bergmann, E. H. Pereira, P. V. Azevedo \& A. Ramires. MCP 16117 (10, 46.7-74.8 mm SL), and UMMZ 225499 (5, 58-70 mm SL), same locality as MCP 12996, 12 Dec 1992, P. H. Wimberger, R. E. Reis \& C. S. Fontana. UFRGS 15743 (3, 107.5-127.5 mm SL), arroio Lajeado Romana, Três Passos, $27^{\circ} 27^{\prime} 24.5^{\prime \prime} \mathrm{S} 53^{\circ} 50^{\prime} 46.5^{\prime} \mathrm{W}, 25$ Oct 2011, J. Anza. UFRGS 15752 (3, 88-114.34 mm SL), arroio do Tigre, tributary to

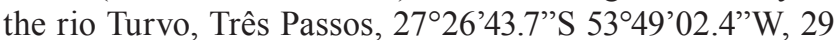
Oct 2011, J. Anza. UFRGS 7551 (2, 59.9-77.6 mm SL), rio Jacutinga, linha Canavesi, near to CASAN station of water

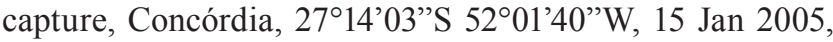
J. Scalcon. UFRGS 7552 (1, $106.6 \mathrm{~mm} \mathrm{SL})$, same locality as UFRGS 7551, 30 Oct 2004, J. Scalcon. UFRGS 7553 (1, $125 \mathrm{~mm} \mathrm{SL}$ ), rio Jacutinga, Linha Unidos, on lower portion of Itá reservoir, Arabutã, $27^{\circ} 09^{\prime} 37^{\prime \prime} \mathrm{S} 52^{\circ} 08^{\prime} 30^{\prime \prime} \mathrm{W}, 30 \mathrm{Oct}$ 2004, J. Scalcon.

Additional non-type specimens. Rio Grande do Sul: MCP 11123 (13), sanga Águas Frias, ca. $100 \mathrm{~m}$ from its mouth into rio Uruguay, Iraí, approx. $27^{\circ} 12^{\prime} \mathrm{S} 53^{\circ} 16^{\prime} \mathrm{W}, 22$ Dec 1985. MCP 12252 (4), rio Uruguay on road BR-153, Marcelino Ramos, approx. $27^{\circ} 22^{\prime} \mathrm{S} 52^{\circ} 01^{\prime} \mathrm{W}, 17$ Oct 1988. MCP 12299 (11), flooded area of rio Dourados at Mariano Moura, 17 Aug 1988. MCP 18556 (2), rio Dourados between Três Barras and Mariano Moro, Mariano Moro, approx. 27²2’S 52¹4’W, 21 Sep 1995. MCP 18982 (10), same locality as MCP 18556, 16 Jan 1996. MCP 19059 (2), same locality as MCP 18556, 17 Apr 1996. MCP 18575 (1), rio Uruguay between confluences with rio Passo Fundo and rio Chapecó, Erval Grande, approx. $27^{\circ} 13^{\prime} \mathrm{S} 52^{\circ} 49^{\prime} \mathrm{W}, 22$ Sep 1995. MCP 18978 (3), same locality as MCP 18575, 17 Jan 1996. MCP 40083 (2 alc.), rio Passo Fundo, Barra do

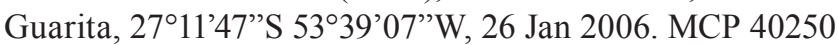

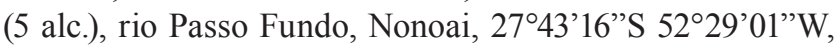
06 Apr 2006. UFRGS 10303 (10), Monjolinho Hydroeletric

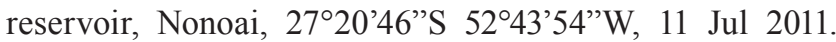
UFRGS 15740 (7), rio Turvo, Três Passos, 2727'15”S 5350'29”W, 29 Oct 2011. Santa Catarina: MCP 12118 (8), rio Uruguay at Alto Feliz, $6 \mathrm{~km}$ from Terra Vermelha, Itá,

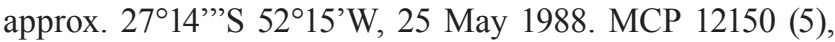
rio Jacutinga at road BR-283, Concórdia, aprox. $27^{\circ} 09^{\prime} \mathrm{S}$ $52^{\circ} 09^{\prime} \mathrm{W}, 25$ Jun 1988, E. Lerner. MCP 12253 (11), rio Uruguay at Itá, approx. $27^{\circ} 17^{\prime} \mathrm{S} 52^{\circ} 19^{\prime} \mathrm{W}, 16$ Aug 1988. MCP 12312 (39), same locality as MCP 12253, 16 Oct 1988. MCP 12512 (3), same locality as MCP 12253, 1-2 Oct 1988. MCP 12923 (5), same locality as MCP 12253, 7-8 Dec 1988. MCP 13345 (4), same locality as MCP 12253, 15-16 Feb 1989. MCP 18977 (1), same locality as MCP 12253, 12 Jan 1996. MCP 12518 (17), rio Jacutinga on road BR-283 from Seara to Concórdia, Concórdia, approx. $27^{\circ} 09^{\prime} \mathrm{S} 52^{\circ} 09^{\prime} \mathrm{W}$,
2 Feb 1988. MCP 13342 (18), same locality as MCP 12518 , 16 Feb 1989. MCP 18979 (1), same locality as MCP 12518, 14 Jan 1996. MCP 18980 (2), rio do Engano (or rio Uvá), on road between Itá and Seara, approx. $27^{\circ} 08^{\prime} \mathrm{S} 52^{\circ} 13^{\prime} \mathrm{W}$, 13 Jan 1996. MCP 18981 (2), rio Rancho Grande on road between Piritiba and highway BR-153, Concórdia, approx. 27 $21^{\prime} \mathrm{S} 51^{\circ} 57^{\prime} \mathrm{W}, 11$ Jan 1996. MCP 20399 (3 alc.), rio Uruguay, Mondaí, 2706’30”S 53²8’33”W, 02 May 1997. MCP 20812 (2 alc.), rio Macaco Branco on road Iporã do Oeste to Tunápolis, Tunápolis, 26 58'39"S 5337'24"W, 28 Jan 1998. MCP 20869 (3 alc.), arroio da Taipa $13 \mathrm{~km}$ from Mondaí, Mondaí, 2707'46”S 53²8'22”W, 27 Jan 1998. MCP 20873 (6 alc.), rio Jundiá on road São Pedro to Tunápolis, Itapiranga, 2701'17’'S 53³8'58”W, 27 Jan 1998. MCP 20919 (13 alc.), rio Iracema and Tributary, Riqueza, $27^{\circ} 08^{\prime}$ 'S 5320’W, 26 Jan 1998.UFRGS 10900 (2), rio Barra Grande tributary of rio Uruguay, about $7 \mathrm{~km}$ from Palmitos,

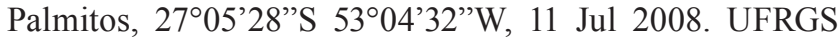
10918 (2), rio Dourados on Vila Dourados near locality of Santa Cruz, Itapiranga, $27^{\circ} 08^{\prime} 20^{\prime \prime} \mathrm{S} 53^{\circ} 39^{\prime} 54^{\prime \prime} \mathrm{W}, 12 \mathrm{Dec}$ 2007. UFRGS 10923 (2), rio Macaco Branco on locality

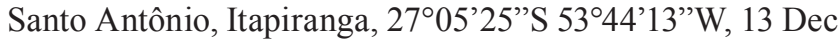
2007.

Diagnosis. Gymnogeophagus lipokarenos is diagnosed from all congeners by the bright yellow color pattern of the unpaired fins ( $v s$. mostly red in other species), covered with white dots aligned between rays; distal border of dorsal fin and dorsal and ventral contours of caudal fin red with thin light stripes. The adipose hump in mature males is prominent, extending dorsally above the tip of the longest dorsal-fin spines ( $v s$. less developed).

Description. Morphometric data summarized in Table 5. Body elongate, laterally compressed. Dorsal profile of head convex between mouth and interorbital area in young, slightly convex in adults; slightly convex from interorbital region to dorsal-fin origin. Predorsal body profile modified in adult males which may have very large adipose hump between nostrils and dorsal-fin origin. Adipose hump sometimes surrounding origin of dorsal fin in large males (Fig. 11). Dorsal-fin base convex. Caudal peduncle longer than deep, with dorsal and ventral profile slightly concave.

Snout slightly blunt and rounded dorsally in young; slightly rounded dorsally and slightly rounded to nearly straight ventrally in adults; narrow and anteriorly rounded in dorsal aspect. Eye small, close to dorsal profile of head in juveniles and progressively farther in larger specimens (about one half eye diameter in specimens larger than 70 $\mathrm{mm} \mathrm{SL}$ ); eye slightly posterior or near middle of head length. Interorbital area convex, more strongly so in larger specimens; interorbital width smaller than one eye diameter in young (up to $50 \mathrm{~mm} \mathrm{SL}$ ) and progressively larger than one eye diameter in larger specimens. Posterior tip of maxilla not reaching vertical line across anterior margin of eye. Upper jaw equal or slightly longer than lower jaw. 
Body scales large and ctenoid, smaller around pectoral fins; scales cycloid in preventral area. Caudal fin with single series of small ctenoid and elongated scales between contiguous rays reaching proximal third of fin in both upper and lower lobes. Soft portion of dorsal fin of males without scales between contiguous rays. Cheek scales cycloid in 4 or 5 rows; cheek naked anteroventrally. Opercle mostly scaled, especially dorsally. Subopercular scales ctenoid in one or two irregular rows. Upper lateral line 14(1), 17*(6), 18(5), 19(1); lower lateral line 8(1), 9*(4), 10(4), 11(4), with 1 to 3 small perforated scales continuing onto caudal-fin base. Scales between upper lateral line and dorsal fin $4^{*}(9), 5(12)$. Scales between upper lateral line and anal fin $8^{*}(6), 9(7)$. E1 scales 25(1), 26*(8), 27(4).

Dorsal-fin spines $13^{*}(2), 14(11)$; dorsal-fin soft rays 9(5), 10(5), 11*(3). First dorsal-fin spine inserted slightly anterior to vertical line across posterior bony margin of opercle. Soft dorsal fin in young rounded, slightly pointed in adult females, reaching to or almost reaching caudalfin base. Soft dorsal fin in mature males pointed, with 3rd or 4th ray longest, reaching proximal third to distal half of caudal fin. Anal-fin with 3 spines (one specimen with 4) and 7(1), 11(8), 9*(1) soft rays. Anal-fin origin under last dorsal-fin spine or first soft ray; soft portion nearly rounded in young and females and clearly pointed in males. Pectoral fin with rounded tip in young and slightly pointed in adults; 3rd ray longest, reaching to or slightly passing vertical crossing anal-fin origin. Pelvic fin pointed, more conspicuously so in adult males; 2nd soft ray longest reaching area of anal opening in females and passing anal-fin origin in mature males. Caudal-fin margin concave.
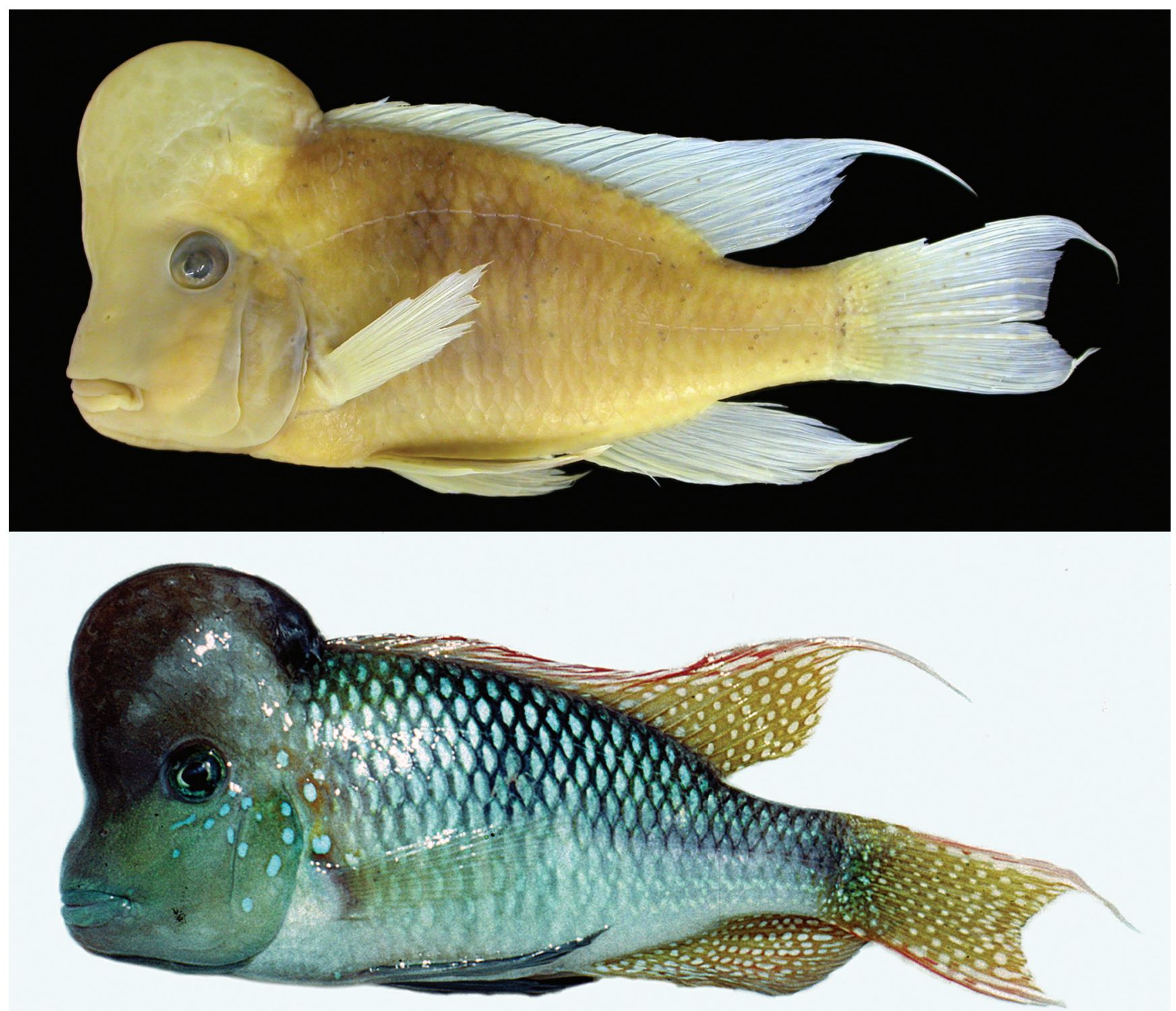

Fig. 11. Gymnogeophagus lipokarenos: top, holotype, male, MCP 23522, $108.5 \mathrm{~mm}$ SL, rio Dourados at Linha Várzea, on the road from Severiano de Almeida to Aratiba, Rio Grande do Sul, Brazil; bottom, holotype, photo taken just after capture. 
Jaw teeth small, conical, with slightly recurved tips. Upper jaw with outer regular row of 14-25 teeth in each premaxilla (number increasing with specimen size) distinct from irregular tooth band of slightly smaller teeth. Lower jaw with narrow tooth band arranged in 3-4 irregular rows; all teeth with approximately same size. Outer hemiseries with 18-22 teeth. Lower limb of first gill arch with 6-9 gill rakers; upper limb lobed with 5-7 gill rakers on its margin. Number of gill rakers increasing with age.

Lower pharyngeal tooth plate slightly wider than long; length of bone $92 \%$ of width; teeth covering occlusion surface; 19-20 teeth in posterior row, 17 on median row. Lateral marginal teeth smaller on caudal half of plate; posteromedial teeth much larger, cylindrical with medial, blunt cusps of molariform aspect (Fig. 6e).

Vertebrae $13+15$ in three cleared and stained specimens.

Table 5. Morphometrics of Gymnogeophagus lipokarenos. Specimens are from MCP 23522 (holotype) and MCP 12958 (paratypes). Ranges include holotype.

\begin{tabular}{lccccc}
\hline Character & Holotype & $\mathrm{n}$ & Range & Mean & SD \\
\hline Standard Length (mm) & 108.5 & 12 & $56.7-123.4$ & 84.5 & \\
& Percents of standard length \\
Body depth & 41.4 & 12 & $38.8-45.3$ & 41.8 & 1.9 \\
Head length & 31.9 & 12 & $32.5-34.9$ & 33.9 & 0.6 \\
Dorsal-fin base & 57.1 & 11 & $51.2-57.1$ & 53.8 & 1.0 \\
Pectoral-fin length & 32.8 & 6 & $30.1-34.6$ & 31.7 & 1.7 \\
Caudal peduncle depth & 14.2 & 11 & $13.4-15.1$ & 14.1 & 0.5 \\
Caudal peduncle length & 15.9 & 11 & $14.1-17.9$ & 16.0 & 1.2 \\
& Percents of head length & & \\
Horizontal eye diameter & 26.0 & 11 & $22.4-31.4$ & 27.0 & 2.1 \\
Interorbital width & 34.1 & 12 & $25.8-34.1$ & 30.3 & 2.3 \\
Upper jaw length & 35.8 & 12 & $30.4-36.4$ & 33.3 & 1.5 \\
Preorbital width & 44.5 & 12 & $27.3-44.5$ & 33.4 & 3.5 \\
Snout length & 52.6 & 12 & $36.6-52.6$ & 43.6 & 3.8 \\
\hline
\end{tabular}

Color in alcohol. Mature males (Figs. 11a, 12a): ground color of body light brown laterodorsally and light brown lateroventrally. Nine to 14 dark double vertical bars hardly discernible along midlateral surface of body, distributed between pectoral-fin base and vertical through last anal fin ray origin, not seen in caudal peduncle. Number of vertical bars increase from small to large specimens. Midlateral spot present but without defined borders, on scales 8-10 or 9-11 of upper lateral line and of two scale rows below upper lateral line. Dark band in front of dorsal-fin origin, extending ventrally and slightly posteriorly. Head light brown, with difuse dark markings ventral and posterior to eye and in upper portion of opercle. Snout and adipose hump dusky. Dark band covering cheek absent. Isthmus and branchiostegal membrane light brown. Pectoral fin hyaline. Pelvic fin dark brown. Dorsal fin faint brown with small, narrow white stripes on spiny portion and circular white spots on soft portion. Anal and caudal fins faint brown covered with circular white dots. Color in alcohol of preserved females (Fig. 12b) and juveniles not clearly distinct from that described for males. Most differences related to isthmus and branchiostegal membrane light brown, instead of dark brown as observed in males, and presence of conspicuous vertical dark band covering cheek, below eye.

Color in life. Vertical bars not visible in freshly collected mature males (Fig. 11b). Ground color of dorsal region of body in males bluish green with longitudinal series of bright spots along scale rows. Middorsal region including adipose hump dark blue. Head largely greenish blue with few red markings on cleithrum. Light blue spots below and posterior to eye, opercle and on body surface above pectoral fin. Lateroventral color bluish white with parts of vertical bars barely discernible. Dorsal fin red with white stripes in spinous portion, and along dorsal border; soft portion yellow covered with round white spots. Caudal fin yellow covered with white spots; dorsal and ventral borders red with white stripes. Most of anal fin yellow covered with white spots; distal region with white stripes. Pectoral fin hyaline; pelvic fin dark.

Distribution. Gymnogeophagus lipokarenos is found in the upper portion of the rio Uruguay drainage and its main tributaries (Fig. 1).

Etymology. From the Greek lipos, meaning fat, and from the Greek kara, meaning head, in allusion to the extremely large adipose hump of adult males (Fig. 11). A noun in apposition.

Conservation status. Gymnogeophagus lipokarenos is frequent and abundant in the upper rio Uruguay. Despite its Extent of Occurrence (EOO) is approximately 7,600 square kilometers, no specific threats were detected, and the species can be categorized as Least Concern (LC) according to IUCN criteria (IUCN, 2014).

\section{Discussion}

The rio Uruguay harbors an extraordinary richness and endemism of several fish groups such as Australoheros, Crenicichla, Cyanocharax, Hisonotus, Hypostomus, Loricariichthys and Rineloricaria (Ričan \& Kullander, 2008; Lucena \& Kullander, 1992; Malabarba \& Weitzman, 2003; Aquino et al., 2001; Reis et al., 1990; Reis \& Pereira, 2000; Ghazzi, 2008, respectively). This high richness and degree of endemism is also seen in Gymnogeophagus, with 10 of the 16 extant species of the genus occurring in the Uruguay river basin. One of them, G. lipokarenos, is endemic to the upper portion of the rio Uruguay, corresponding to the Upper Uruguay Ecoregion (Fig. 1; unit 333 - Abell et al., 2008), while G. constellatus, G. mekinos, G. meridionalis, G. missioneiro, G. pseudolabiatus, and G. tiraparae are endemic to the Lower Uruguay Ecoregion, that includes the rio Negro 
(Fig. 1; unit 332 - Abell et al., 2008). Three of these species (G. constellatus, G. missioneiro, and G. pseudolabiatus) have more limited distributions, being each endemic to a single tributary of the rio Uruguay and absent in the rio Negro. Limited geographic distribution is uncommon among Neotropical cichlids (Nogueira et al., 2010) and it may be related to ecological or historical constrains. It is remarkable that among the seven species of the G. gymnogenys clade occurring in the rio Uruguay (G. australis, G. constellatus, $G$. lipokarenos, G. mekinos, G. missioneiro, G. pseudolabiatus and G. tiraparae), only G. mekinos and G. tiraparae are found syntopically in a few places, and this may reflect habitat specificity constrains for these species.

The five new species described herein are included in a putatively monophyletic clade first hypothesized by Reis \& Malabarba (1988) and including G. australis and G. gymnogenys. Characters proposed to define this clade are related to general color pattern, and can be easily recognized among Gymnogeophagus species. The presence of a black band from nape to cheek and crossing the eye is a plesiomorphic and common character found among Neotropical cichlids. It is also observed in G. balzanii (Fig. 13a, b), G. che, G. labiatus (Fig. 13e, f), G. lacustris (Fig. 13g, h), G. meridionalis (Fig. 13c), G. rhabdotus (Fig. $13 \mathrm{~d}$ ), and G. setequedas. The new species described herein, however, along with G. australis, G. caaguazuensis, G. gymnogenys (Fig. 2) and G. tiraparae (Fig. 13i, j), lack the segment from the nape to the upper orbital rim, with only the mark on the cheek persisting, which represents one synapomorphy for this clade. The second synapomorphy that allows the recognition of a monophyletic clade including G. australis, G. constellatus, G. caaguazuensis, G. gymnogenys, G. lipokarenos, G. mekinos, G. missioneiro, G. pseudolabiatus and G. tiraparae is the possession of a black bar originating in the dorsal contour near dorsal-fin origin and directed downward and backward in the flank. The last character is easily observable in juveniles and usually in females of all species of the G. gymnogenys clade and allows their immediate recognition from the remainder Gymnogeophagus species.
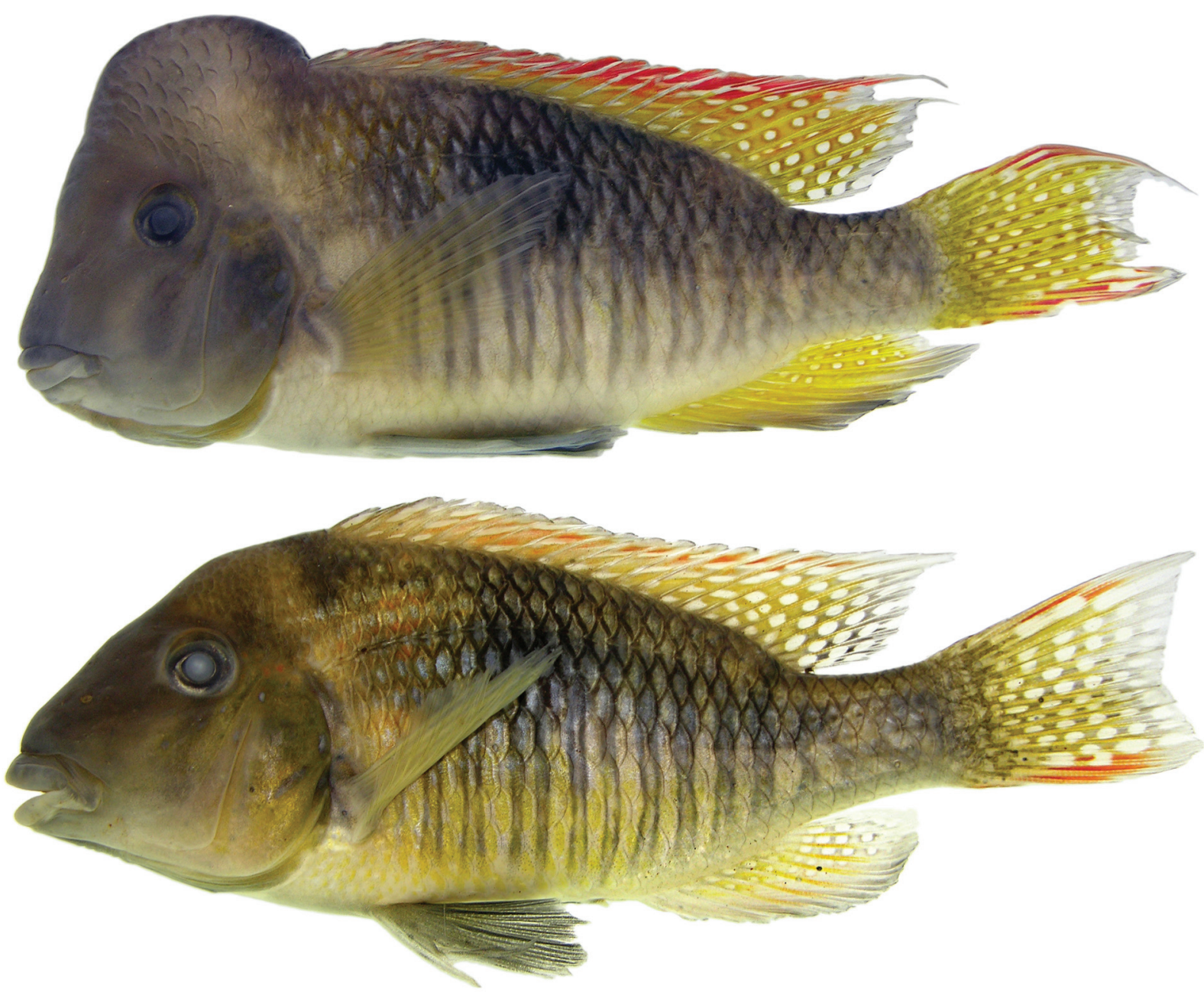

Fig. 12. Gymnogeophagus lipokarenos: top, paratype, male, UFRGS 15752, $115 \mathrm{~mm}$ SL, arroio do Tigre, tributary of the rio Turvo, Três Passos, Rio Grande do Sul, Brazil; bottom, paratype, female, UFRGS 15743, 107 mm SL, arroio Lajeado Romana, Três Passos, Rio Grande do Sul, Brazil. 

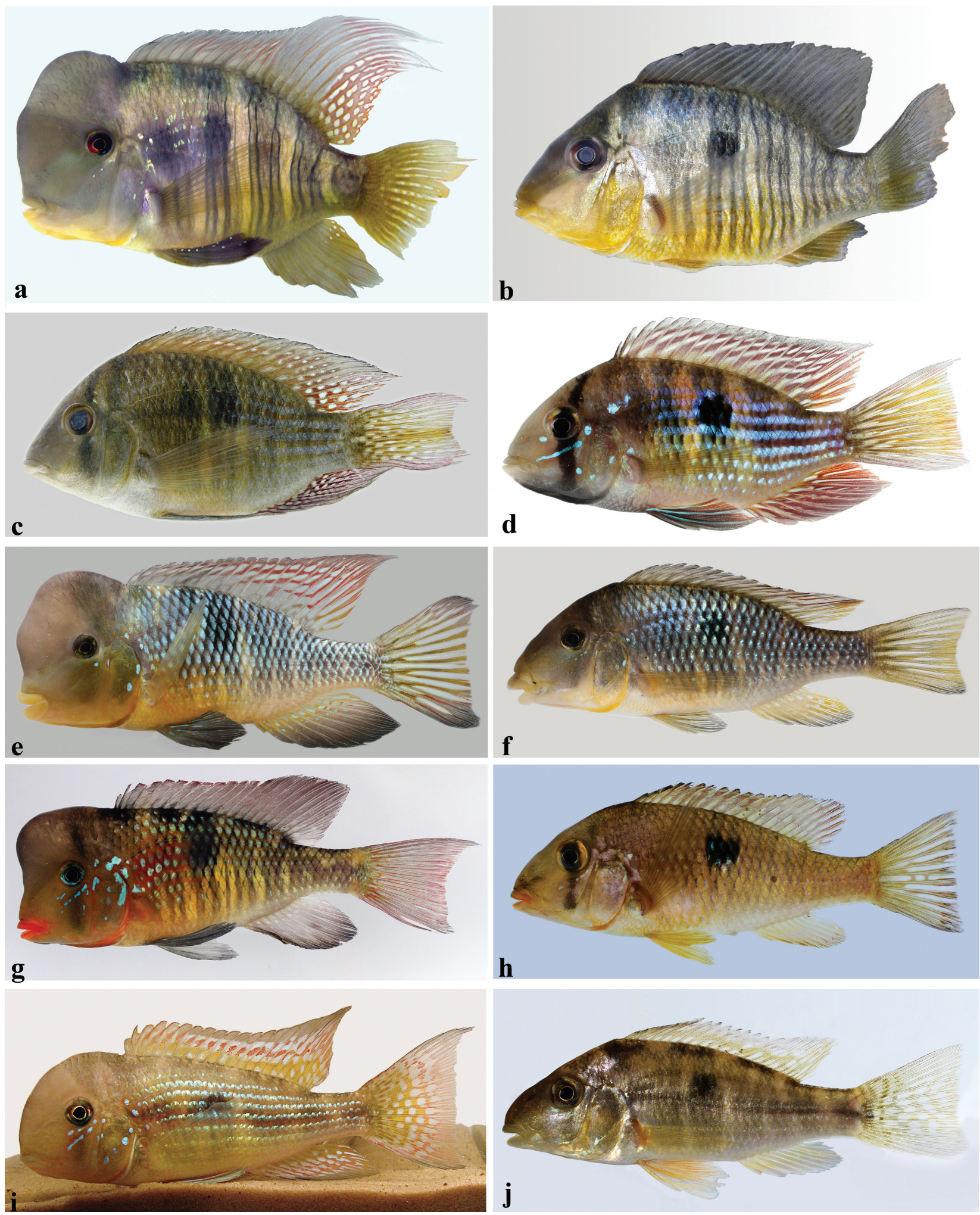

Fig. 13. Species of Gymnogeophagus from Rio Grande do Sul State, Brazil. a, Gymnogeophagus balzanii, male, UFRGS 9148, 131.8 mm SL, barragem Sanchuri, Uruguaiana. b, G. balzanii, female, UFRGS 7015, 86 mm SL, barragem Sanchuri, Uruguaiana. c, G. meridionalis, male, UFRGS 8404, rio Negro, BR-153, between Aceguá and Bagé. d, G. rhabdotus, male, uncat., $65 \mathrm{~mm} \mathrm{SL}$, EEA-UFRGS, Eldorado do Sul. e, G. labiatus, male, uncat., $117 \mathrm{~mm}$ SL, lago Guaíba. f, G. labiatus, female, uncat., 104 mm SL, Barra do Ribeiro. g, G. lacustris, male, UFRGS 16751, 128 mm SL, lagoa Corvina, Mostardas. h, G. lacustris, female, UFRGS 16751, 90 mm SL, lagoa Corvina, Mostardas. i, G. tirapare, male, uncat., rio Cacequi. j, G. tirapare, female, UFRGS 16642, rio Santa Maria, Rosário do Sul. 
The monophyly of this clade was also supported by Wimberger et al. (1998) phylogeny of Gymnogeophagus based on the analysis of 713 base pairs of mitochondrial DNA, that groups $G$. lipokarenos (named therein Gymnogeophagus sp. E), G. mekinos (Gymnogeophagus sp. A), G. missioneiro (Gymnogeophagus sp. D), G. pseudolabiatus (Gymnogeophagus sp. C) and G. tiraparae (Gymnogeophagus sp. B) in a monophyletic clade along with G. gymnogenys, and that excludes G. balzanii, G. labiatus, G. lacustris, G. meridionalis, G. rhabdotus, and G. setequedas. Gymnogeophagus constellatus was not available and not included in that analysis. The monophyly of the G. gymnogenys clade was further tested by Pereyra \& García (2008), that found the populations of the G. gymnogenys complex monophyletic, including four clades: clade 1 (=G. mekinos in this study), clade 2 (=G. pseudolabiatus in this study), clade $3(=$ G. tiraparae according to González-Bergonzoni et al., 2009), and clade 4 (=G. gymnogenys, stricto sensu). Gymnogeophagus labiatus and G. meridionalis were recovered apart from their G. gymnogenys clade.

Gymnogeophagus labiatus and G. pseudolabiatus have hyperthrophied lips, but both morphological and molecular evidences indicate this is a convergence. Lip hypertrophy is often associated with grazing rocky surfaces and with incipient species in lentic cichlids (Elmer et al., 2010; Burress et al., 2013). Whereas lip hypertrophy is common in lentic cichlids (Elmer et al., 2010), it is known in just a few lotic species, e.g., Gymnogeophagus labiatus, G. pseudolabiatus, and Crenicichla tendybaguassu. Besides the two Gymnogeophagus species, this distinct lip morphology is also seen in the South American Crenicichla tendybaguassu (rio Uruguay drainage), in Amphilophus citrinellus and A. labiatus from Central America, and Abactochromis labrosus, Chilotilapia euchilus, Haplochromis chilotes, Lobochilotes labiatus, Otopharynx pachycheilus, Placidochromis milomo, and Promelas ornatus from the East African Great Lakes. According to Burress (2015), among the sensorial and mechanical functions (Arnegard \& Snoeks, 2001; Fryer, 1959; Fryer \& Iles, 1972) attributed to this morphology, the most accepted hypothesis supposes an improvement of suction by sealing cracks and grooves. Others have suggested that it can also be used to extend the substrate for taste buds (Arnegard \& Snoeks, 2001), mechanoreceptors (Fryer, 1959; Fryer \& Iles, 1972), or protection from mechanical shocks during foraging on rocks (Greenwood, 1974). Hypertrophied lips have evolved separately and several times in cichlids in Africa, Central and South America (Burress, 2015), and this seems to be the case also for G. labiatus and $G$. pseudolabiatus that are found respectively inhabiting rocky bottom rivers from the laguna dos Patos and rio Tramandaí drainages and from the rio Quaraí and tributaries. Interestingly, G. constellatus, G. lipokarenos, and $G$. missioneiro are all found in rocky bottom environments, but do not show hyperthrophied lips.
Key to the species of Gymnogeophagus (some characters apply only for males):

1. Dorsal-fin with $12-15$ branched rays; caudal-fin almost completely scaled, with lateral line ramus in its lower lobe G. balzanii (Fig. 13a,b; rio Guaporé, rio Paraguay, lower rio Paraná and rio Uruguay)

1'. Dorsal-fin with 8-12 branched rays; caudal-fin with scales restricted to the proximal third or half length, without lateral line ramus in its lower lobe.................................. 2

2. Caudal peduncle length equal or shorter than its depth; E1 series with 22-25 scales (24-26 in G. che) ................ 3

2'. Caudal peduncle longer than its depth; E1 series with 25-29 scales

3. Bright-blue longitudinal flank striping very conspicuous; color pattern of unpaired fins formed by conspicuous small stripes .............................. G. rhabdotus (Fig. 13d; coastal streams of southern Brazil and rio Uruguay)

3'. Bright-blue longitudinal flank striping faint or hardly visible; color pattern of unpaired fins without conspicuous stripes ..... . .4

4. Dorsal and anal fin with well-defined circular dots .......... .........G. meridionalis (Fig. 13c; lower rio Paraná and rio Uruguay)

4. Color pattern of unpaired fins very faint, without conspicuous dots or stripes ........................................... 5

5. Snout pronounced (snout length $32.2-55.9 \%$ of head length, mean $=45.2 \%$ ); dorsal and anal fins with elongate obliquous bars; caudal-fin base with elongate horizontal gray bars alternated with white bars reaching half-length of the caudal fin G. che (arroyo Urugua-í, rio Paraná drainage)

5'. Snout short, not pronounced (snout length $30.8-44.7 \%$ of head length, mean $=36.4 \%$ ); soft dorsal fin with small light stripes; anal fin with few inconspicuous light stripes; caudal fin without conspicuous marks.......G. setequedas (tributaries of middle rio Paraná)

6. Dark band from dorsal-fin origin to cheek, crossing the eye; dorsal and caudal fins with longitudinal stripes, sometimes plain; anal fin with one or two series of small dots near its base 7

6'. Dark band extends posteroventrally from dorsal-fin origin, never extending to the eye; dorsal, anal, and caudal-fin partially or completely covered with well defined circular dots ...................................................... 8

7. Lips thick, extremely well developed, lower lip deeply notched medially ......................... . labiatus (Fig. 13e, f; laguna dos Patos drainage and Serra Geral tributaries to the rio Tramandaí drainage)

7'. Lips thin, not excessively developed or notched ........ G. lacustris (Fig. 13g, h; coastal lagoons of the rio Tramandaí drainage)

8. Lips thick, extremely well developed, lower lip deeply notched medially ................... G. pseudolabiatus (Fig. 4; rio Quaraí and tributaries)

8'. Lips normal, not excessively developed or notched..............9 
9. Mature males with a conspicuous and oblique dark band from the eye to the anterior border of head (Figs. 2a, 7) 10

9'. Mature males without an oblique dark band from the eye to the anterior border of head. 11

10. Body very elongated; body depth in specimens larger than $65 \mathrm{~mm} \mathrm{SL}, 34.9-38.3 \% \mathrm{SL}(\mathrm{n}=13$; mean $=36.7 \%)$. G. mekinos (Fig. 7; rio Negro)

10 '. Body elongated; body depth in specimens larger than 65 $\mathrm{mm}$ SL, 38.6-44.2 \% SL $(\mathrm{n}=15$; mean $=40.6 \%)$.......... G. gymnogenys (Fig. 2; laguna dos Patos drainage and rio Tramandaí drainage)

11. Snout excessively blunt with anteriormost section of its dorsal profile nearly vertical; presence of two or three narrow longitudinal white stripes along posterior spinous dorsal fin, becoming fused in a large white longitudinal stripe along midlength of soft dorsal-fin rays in mature males ............................................................... G. tirapare (Fig. 13i, j; rio Negro and rio Ibicuí drainage into rio Uruguay)

11'. Snout profile straight or slightly convex; dorsal fin not as above 12

12. Upper lateral line with $18-21$ scales. Scales of the midlateral spot each bearing a large white dot .. G. constellatus (Fig. 9; rio Ijuí drainage)

12.'Upper lateral line 13-19. Scales of the midlateral black spot without white dots 13

13. Soft dorsal fin scaled......... G. australis (rio de La Plata)

13 '. Soft dorsal fin not scaled ... 14

14. Dorsal, anal, and caudal fins mostly yellow, with distal border of dorsal fin and dorsal and ventral contours of caudal fins red, and covered with translucent dots

G. lipokarenos (Figs. 11-12; upper rio Uruguay)

14. Dorsal, anal, and caudal fins red and covered with translucent dots or stripes. .. 15

15. Soft dorsal fin with white dots forming stripes distally.... G. missioneiro (Fig. 10; rio Piratini drainage) 15'. Entire dorsal fin with spaced silvery to bright blue dots G. caaguazuensis (Lower rio Paraguay drainage)

Comparative material examined. Material examined in addition to that listed by Reis \& Malabarba (1988), Reis et al. (1992) and Malabarba et al. (2010). Gymnogeophagus balzanii: Brazil: UFRGS 9148, 1, 131.8 mm SL, UFRGS 7015, 1 of 2, Rio Grande do Sul, Uruguaiana, Sanchuri dam. Gymnogeophagus gymnogenys: Brazil: UFRGS 17259, 1, 120 mm SL, Rio Grande do Sul, Mostardas, lagoa Corvina. Gymnogeophagus lacustris: Brazil: UFRGS 16751, 2 of 8, 90-128 mm SL, Rio Grande do Sul, Mostardas, lagoa Corvina. Gymnogeophagus meridionalis: Brazil: UFRGS 8404,1 of 8, $94.2 \mathrm{~mm} \mathrm{SL}$, Rio Grande do Sul, Bagé, rio Negro on road BR-153, between Aceguá and Bagé. Gymnogeophagus tiraparae: Brazil: MCP 16124, 6, 47.7-85.4 mm SL, MCP 18295, 1, 78.8 mm SL, MCP 18362, 12, 33.5-66.1 mm SL, UFRGS 16642, 1, 56 mm SL, Rio Grande do Sul, Rosário do Sul, rio Santa Maria; MCP 26783, 36, 29.4-58.5 mm SL, MCP 16218, 3, 24-51.3 mm SL, Rio Grande do Sul, Santana do
Livramento, arroio Ibicuí da Faxina on BR-158; MCP 27542, 14, 27.3-66.7 mm SL, Rio Grande do Sul, arroio do Tigre on BR 453 to Ijucapirama; MCP 9316, 5, 28-43.3 mm SL, Rio Grande do Sul, São Francisco de Assis, rio Jaguari; MCP 9357, 8, 23.2-94.3 mm SL, Rio Grande do Sul, Cacequi, rio Saicã; MCP 9382, 5, 30.6$42.5 \mathrm{~mm}$ SL, Rio Grande do Sul, Cacequi, rio Ibicuí on the bridge between São Rafael and Cacequi; MCP 9412, 5, 41.3-67.2 mm SL, Rio Grande do Sul, Cacequi, rio Cacequi between Cacequi and São Simão; MCP 9445, 3, 46.9-69.8 mm SL, Rio Grande do Sul, Cacequi, rio Santa Maria on road to São Simão; MCP 9837, 3, 48.5-72.6 mm SL, Rio Grande do Sul, Bagé, arroio on $\mathrm{km} 45$ of BR-153, between Bagé and Aceguá. Uruguay: UFRGS 7309, 52, 26-66.4 mm SL, Tacuarembó, río Tacuarembó, on Ruta 26 in Villa Ansina. UFRGS 7370, 18, 22.6-52.5 mm SL, Durazno, río YI, on road to San Borja; UFRGS 7432, 7, 22.4-73.8 mm SL, Tacuarembó, río YI, tributary of rio Negro.

\section{Acknowledgements}

The authors are especially grateful to Douglas Nelson (UMMZ) for loan of specimens under his care and in solving collecting locality records of some specimens housed in UMMZ. We thank Marcelo Loureiro (ZVCP) and Fernando Meyer (MAPA) for the loan of specimens, Felipe Cantera for help during the field work and Peter Wimberger for the photos illustrating Figs. 5 top, 7, 8 middle, 10 bottom, and 11 bottom. RER is grateful to Carlos Lucena and Margarete Lucena for continued support at the Laboratory of Ichthyology of MCP. Financial support was provided by the Conselho Nacional de Desenvolvimento Científico e Tecnológico (CNPq, Brazil) to LRM (processes \#300705/2010-7 and 477318/2012-6), MCM (process \#151054/2013-4), and RER (processes \#305180/2010-0 and \#207038/2013-9), and the Fundação de Amparo à Pesquisa do Estado do Rio Grande do Sul (FAPERGS) to RER (process \# 11/0936-5).

\section{References}

Abell, R., M. L Thieme, C. Revenga, M. Bryer, M. Kottelat, N. Bogutskaya, B. Coad, N. Mandrak, S. C. Balderas, W. Bussing, M. L. J. Stiassny, P. Skelton, G. R. Allen, P. Unmack, A. Naseka, R. Ng, N. Sindorf, J. Robertson, E. Armijo, J. V. Higgins, T. J. Heibel, E. Wikramanayake, D. Olson, H. L. López, R. E. Reis, J. G. Lundberg, M. H. Sabaj Pérez \& P. Petry. 2008. Freshwater ecoregions of the World: a new map of biogeographic units for freshwater biodiversity conservation. BioScience, 58: 403414.

Aquino, A. E., S. A. Schaefer \& A. M. Miquelarena. 2001. A new species of Hisonotus (Siluriformes, Loricariidae) of the upper Río Uruguay basin. American Museum Novitates, 3333: 1-12.

Arnegard, M. E. \& J. Snoeks. 2001. New three-spotted cichlid species with hypertrophied lips (Teleostei: Cichlidae) from the deep waters of Lake Malawii/Nyasa, Africa. Copeia, 2001: 705717.

Burress, E. D. 2015. Cichlid fishes as models of ecological diversification: patterns, mechanisms, and consequences. Hydrobiologia, 748: 7-27. 
Burress, E. D., A. Duarte, W. S. Serra, M. Loueiro, M. M. Gangloff \& L. Siefferman. 2013. Functional diversification within a predatory species flock. PLoS ONE, 8: e80929 (p. 1-10).

Casciotta, J. R., S. E. Gómez \& N. I. Toresanni. 2000. Gymnogeophagus che, una nueva especie de la familia Cichlidae de la cuenca del río Paraná (Perciformes, Labroidei). Revista del Museo Argentino de Ciencias Naturales, 2: 53-59.

Eigenmann, C. H. 1907. On a collection of fishes from Buenos Aires. Proceedings of the Washington Academy of Sciences, 8: 449-458.

Elmer, K. R., T. K. Lehtonen, A. F. Kautt, C. Harrod \& A. Meyer. 2010. Rapid sympatric ecological differentiation of crater lake cichlid fishes within historic times. BMC Biology, 8: 60.

Eschmeyer, W. N. \& J. D. Fong. 2015. Species by family/ subfamily in the Catalog of Fishes. California Academy of Sciences. Available from: http://researcharchive.calacademy. org/research/ichthyology/catalog/SpeciesByFamily.asp (5 March 2015).

Fryer, G. \& T. D. Iles. 1972. The cichlid fishes of the great lakes of Africa: their biology and evolution. Edinburgh, Oliver \& Boyd, 641p.

Fryer, G. 1959. The trophic interrelationships and ecology of some littoral communities of Lake Nyasa with especial reference to the fishes, and a discussion of the evolution of a group of rock-frequenting Cichlidae. Proceedings of the Zoological Society of London, 132: 153-281.

Ghazzi, M. S. 2008. Nove espécies novas do gênero Rineloricaria (Siluriformes, Loricariidae) do rio Uruguai, do sul do Brasil. Iheringia, Série Zoologia, 98: 100-122.

González-Bergonzoni, I., M. Loureiro \& S. Oviedo. 2009. A new species of Gymnogeophagus from the río Negro and río Tacuarí basins, Uruguay (Teleostei: Perciformes). Neotropical Ichthyology, 7: 19-24.

Gosse, J. -P. 1976. Révision du genre Geophagus (Pisces, Cichlidae). Mémoire Academie royale des Sciences d'OutreMer. Classe des Sciences Naturelles et Medicales, 19: 1-172.

Greenwood, P. H. 1974. The cichlid fishes of Lake Victoria, East Africa: the biology and evolution of a species flock. Bulletin of the British Museum (Natural History), Zoology, suppl. 6: 1-134.

Hensel, R. 1870. Beiträge zur Kenntniss der Wirbelthiere Südbrasiliens. (Fortsetzung). Archiv für Naturgeschichte, 36: 50-91.

IUCN Standards and Petitions Subcommittee. 2014. Guidelines for using the IUCN Red List Categories and Criteria. Version 11. Prepared by the Standards and Petitions Subcommittee. Available from: http://www.iucnredlist.org/documents/ RedListGuidelines.pdf. (Nov 2014).

Kullander, S. O. 1981. Cichlid fishes from the La Plata basin. Part I. Collections from Paraguay in the Muséum d'Histoire naturelle de Genève. Revue Suisse de Zoologie, 88: 675692.

Kullander, S. O. 1996. Heroina isonycterina, a new genus and species of cichlid fish from Western Amazonia, with comments on cichlasomine systematics. Ichthyological Exploration of Freshwaters, 7: 149-172.

López-Fernández, H., K. O. Winemiller \& R. L. Honeycutt. 2010. Multilocus phylogeny and rapid radiations in Neotropical cichlid fishes (Perciformes: Cichlidae: Cichlinae). Molecular Phylogenetics and Evolution, 55: 1070-1086.
López-Fernández, H., R. L. Honeycutt \& K. O. Winemiller. 2005b. Molecular phylogeny and evidence for an adaptive radiation of geophagine cichlids from South America (Perciformes: Labroidei). Molecular Phylogenetics and Evolution, 34: 227244.

López-Fernández, H., R. L. Honeycutt, M. L. J. Stiassny \& K. O. Winemiller. 2005a. Morphology, molecules, and character congruence in the phylogeny of South American geophagine cichlids (Perciformes, Labroidei). Zoologica Scripta, 34: 627651.

Loureiro, M., A. Duarte \& M. Zarucki. 2011. A new species of Austrolebias Costa (Cyprinodontiformes: Rivulidae) from northeastern Uruguay, with comments on distribution patterns. Neotropical Ichthyology, 9: 335-342.

Lucena, C. A. S. \& S. O. Kullander. 1992. The Crenicichla (Teleostei: Cichlidae) species of the Uruguai River drainage in Brazil. Ichthyological Exploration of Freshwaters, 3: 97-160.

Malabarba, L. R. \& S. H. Weitzman. 2003. Description of a new genus with six new species from southern Brazil, Uruguay and Argentina, with a discussion of a putative characid clade (Teleostei: Characiformes: Characidae). Comunicações do Museu de Ciências e Tecnologia da PUCRS, série Zoologia, 16: 67-151.

Malabarba, M. C., L. R. Malabarba \& C. Del Papa. 2010. Gymnogeophagus eocenicus, n. sp. (Perciformes: Cichlidae), an eocene cichlid from the Lumbrera Formation in Argentina. Journal of Vertebrate Paleontology, 30: 341-350.

Miranda Ribeiro, A. de. 1918. Dois gêneros e três espécies novas de peixes brasileiros determinados nas collecções do Museu Paulista. Revista do Museu Paulista, 10: 787-793.

Nogueira, C., P. A. Buckup, N. A. Menezes, O. T. Oyakawa, T. P. Kasecker, M. B. Ramos Neto \& J. M. C. Silva. 2010. Restricted-range fishes and the conservation of Brazilian freshwaters. PLoS ONE, 5: e11390 (p. 1-10).

Pereyra, S. \& G. García. 2008. Patterns of genetic differentiation in the Gymnogeophagus gymnogenys species complex, a neotropical cichlid from South American basins. Environmental Biology of Fishes, 83: 245-257.

Perugia, A. 1891. Appunti sopra alcuni pesci sud-americani conservati nel Museo Civico di Storia Naturale di Genova. Annali del Museo Civico di Storia Naturale di Genova, (Serie 2a) 10: 605-657.

Reis, R. E. \& L. R. Malabarba. 1988. Revision of the Neotropical cichlid genus Gymnogeophagus Ribeiro, 1918, with descriptions of two new species (Pisces, Perciformes). Revista Brasileira de Zoologia, 4: 259-305.

Reis, R. E., L. R. Malabarba \& C. S. Pavanelli. 1992. Gymnogeophagus setequedas, a new cichlid species (Teleostei: Labroidei) from middle rio Paraná system, Brazil and Paraguay. Ichthyological Exploration of Freshwaters, 3: 265-272.

Reis, R. E. \& E. H. L. Pereira. 2000. Three new species of the loricariid catfish genus Loricariichthys (Teleostei: Siluriformes) from southern South America. Copeia, 2000: 1029-1047.

Reis, R. E., C. Weber \& L. R. Malabarba. 1990. Review of the genus Hypostomus Lacépède, 1803 from Southern Brazil, with descriptions of three new species (Pisces, Siluriformes, Loricariidae). Revue Suisse de Zoologie, 97: 729-766.

Ričan, O. \& S. O. Kullander. 2008. The Australoheros (Teleostei: Cichlidae) species of the Uruguay and Paraná River drainages. Zootaxa, 1724: 1-51. 
Serra, S., J. Bessonart, F. T. de Mello, A. Duarte, L. Malabarba \& M. Loureiro. 2014. Peces del río Negro. Montevideo, MGAPDinara, 207p.

Staeck, W. 2006. Gymnogeophagus caaguazuensis sp. n.-a new species of cichlid fish (Teleostei: Perciformes: Cichlidae) from the drainage of the lower río Paraguay in Paraguay. Zoologische Abhandlungen (Dresden), 56: 99-105.

Taylor, W. R. \& G. C. Van Dyke. 1985. Revised procedures for staining and clearing small fishes and other vertebrates for bone and cartilage study. Cybium, 9: 107-119.
Wimberger, P. H., R. E. Reis \& K. R. Thornton. 1998. Mitochrondrial phylogenetics, biogeography, and evolution of parental care and mating systems in Gymnogeophagus (Perciformes: Cichlidae). Pp. 509-518. In: Malabarba, L. R., R. E. Reis, R. P. Vari, Z. M. S. Lucena \& C. A. S. Lucena (Eds.). Phylogeny and classification of Neotropical fishes. Porto Alegre, Edipucrs.

Submitted December 17, 2014 Accepted June 22, 2015 by Hernán López-Fernández Published December 15, 2015 